\title{
Lycopodiaceae no Parque Nacional do Itatiaia, RJ e MG, Brasil ${ }^{1}$
}

\author{
Carla Gabriela Vargas Ramos ${ }^{2,3}$ e Lana da Silva Sylvestre ${ }^{2}$
}

Recebido em 9/04/2008. Aceito em 29/12/2008

RESUMO - (Lycopodiaceae no Parque Nacional do Itatiaia, RJ e MG, Brasil). O Parque Nacional do Itatiaia localiza-se na região Sudeste do Brasil, nos limites dos estados do Rio de Janeiro e Minas Gerais, com altitudes que variam de 390 a $2789 \mathrm{~m}$ (Pico das Agulhas Negras). Lycopodiaceae apresenta quatro gêneros e cerca de 500 espécies, com distribuição cosmopolita, caracterizando-se pelos microfilos e esporofilos eligulados e pela homosporia. A família está representada na área de estudo por 23 espécies e uma variedade, distribuídas em três gêneros (Huperzia, 15 espécies; Lycopodiella, quatro espécies e uma variedade; Lycopodium, quatro espécies), totalizando $43 \%$ das espécies citadas para o país e $72 \%$, para o estado do Rio de Janeiro. São apresentadas chaves para a identificação de gêneros e espécies, ilustrações, descrições, comentários sobre caracteres diagnósticos e ecológicos, distribuição geográfica e variação altitudinal.

Palavras-chave: Lycopodiaceae, Domínio Florestal Atlântico, taxonomia

ABSTRACT - (Lycopodiaceae of Itatiaia National Park, Rio de Janeiro and Minas Gerais states, Brazil). Itatiaia National Park is located in Southeastern Brazil, between the states of Rio de Janeiro and Minas Gerais, with altitudes ranging from 390 to $2789 \mathrm{~m}$ (Pico das Agulhas Negras). Lycopodiaceae has four genera and approximately 500 species, with cosmopolitan distribution. It is a homosporous family characterized by eligulate leaves and sporophylls. The family is represented in the study area by 23 species and one variety, distributed in three genera (Huperzia, 15 species; Lycopodiella, four species and one variety; Lycopodium, four species), totaling $43 \%$ of the species recorded in Brazil and $72 \%$ in the state of Rio de Janeiro. Keys to the identification of the genera and species, illustrations, descriptions, notes on taxonomy and ecologicalcharacteristics, geographic distribution and altitudinal variation are presented. Key words: Lycopodiaceae, Atlantic Forest, taxonomy

\section{Introdução}

Lycopodiaceae (Lycophyta) apresenta quatro gêneros (Huperzia Bernh., Lycopodiella Holub, Lycopodium L. e Phylloglossum Kunze) e cerca de 500 espécies. Com exceção do gênero monotípico Phylloglossum ( $P$. drummondii Kunze), encontrado na Austrália, Tasmânia e Nova Zelândia, os demais são cosmopolitas (Øllgaard 1987). Monofilética, caracteriza-se por apresentar microfilos e esporofilos eligulados e homosporia (Pryer et al. 2004; Wikström 2001).

Somente para a região Neotropical, contabiliza-se cerca de 183 espécies de Lycopodiaceae. No Brasil, ocorrem 54 espécies e cinco variedades de Lycopodiaceae: Huperzia com 38 espécies, Lycopodiella com 11 espécies e cinco variedades e Lycopodium com cinco espécies (Øllgaard \& Windisch 1987; Øllgaard 1992; 1993; 1995; 1996).

Cerca de $85 \%$ das espécies de Lycopodiaceae ocorrentes no Brasil concentram-se nas regiões Sudeste e Sul. Contudo, não existem tratamentos taxonômicos do grupo que contemplem estas áreas. Aliado a isto, a grande maioria dos representantes da família no Brasil, principalmente as espécies endêmicas para o país, é pouco conhecida do ponto de vista taxonômico.

A área de estudo escolhida foi o Parque Nacional do Itatiaia (PNI), situado na Serra da Mantiqueira, que está incluída em um dos principais centros de diversidade e endemismo de pteridófitas nos Neotrópicos (Tryon 1972). Algumas listas florísticas (Brade 1956; Dusén 1905; 1955; Ule 1895) registraram as espécies de Lycopodiaceae ocorrentes na área, todavia contempla- ram somente a região alto-montana (acima de $1800 \mathrm{~m}$ ). Recentemente, destaca-se o trabalho de Condack (dados não publicados), o qual citou 17 espécies de Lycopodiaceae para a mesma região. Assim, a representação da família para a região abaixo dessa cota altitudinal ainda é pouco conhecida.

Com o objetivo de indicar as espécies ocorrentes na área e avaliar os padrões de distribuição destas, forneceram-se chaves para a identificação de gêneros e espécies, ilustrações, descrições, comentários sobre caracteres diagnósticos e ecológicos, distribuição geográfica e variação altitudinal.

\section{Material e métodos}

A área de estudo - o Parque Nacional do Itatiaia localiza-se na região Sudeste do Brasil, a noroeste do estado do Rio de Janeiro, nos municípios de Itatiaia e Resende, e ao sul do estado de Minas Gerais, nos municípios de Alagoa, Bocaina de Minas e Itamonte, entre as coordenadas $22^{\circ} 29^{\prime}-$ $22^{\circ} 45^{\prime} \mathrm{S} ; 44^{\circ} 15^{\prime}-44^{\circ} 50^{\prime} \mathrm{W}$. Apresenta um amplo gradiente altitudinal de 390 a 2789 m, com as maiores altitudes para o Pico das Agulhas Negras (http://www.ibama.gov.br/parna_itatiaia).

Inserido no Domínio Florestal Atlântico, o PNI possui vegetação classificada como Floresta Ombrófila Densa (Veloso et al. 1991), sendo reconhecidas três delimitações altimétricas: submontana (até $500 \mathrm{~m}$ ), montana (500-1500 m) e alto-montana (acima de $1500 \mathrm{~m}$ ). Os Refúgios Vegetacionais foram tratados como campos de altitude.

Tratamento taxonômico - foram consultados os herbários GUA, HB, R, RB, RBR e PACA (acrônimos segundo Holmgren et al. 1990). O exame deste material serviu para comparação, identificação dos táxons, complementação de descrições e de dados referentes à distribuição geográfica e variação altitudinal.

O trabalho de campo foi realizado no período de maio de 2005 a outubro de 2006. Ao final, coletou-se 63 espécimes de Lycopodiaceae, que correspondem a $87 \%$ das espécies registradas para a área de estudo. Todos os espécimes coletados foram herborizados e incorporados ao acervo do herbário RB

\footnotetext{
1 Parte da Dissertação da primeira Autora

2 Universidade Federal Rural do Rio de Janeiro, Instituto de Biologia, Departamento de Botânica, Seropédica, RJ, Brasil

3 Autor para correspondência: cgvramos@gmail.com
} 
A identificação e revisão nomenclatural dos espécimes basearam-se no sistema de classificação proposto por Øllgaard (1987).

A descrição dos táxons limitou-se àqueles oriundos da área de estudo (material examinado), havendo a complementação dos dados, sempre que necessário, por meio de espécimes de outras áreas (material adicional). Os dados morfológicos utilizados nas descrições e chaves basearam-se em estudos específicos para a família (Øllgaard 1979; 1987; 1992; 1993; 1995; Øllgaard \& Windisch 1987), complementados com termos morfológicos segundo Lellinger (2002).

Neste estudo, padronizou-se a terminologia utilizada para a descrição do caule e ramos de Lycopodium e Lycopodiella. A porção reptante, longoreptante, sarmentosa ou rizomatosa foi chamada de caule primário. Todos os ramos que partem dorsalmente ou lateralmente do caule primário foram chamados de ramos secundários.

Os dados de distribuição geográfica e de variação altitudinal basearam-se em informações contidas na literatura específica para a família (Øllgaard 1992; Øllgaard \& Windisch 1987), complementados pela análise de coleções depositadas em herbários e dos espécimes coletados.

Os comentários referentes aos substratos e ambientes preferenciais seguiram Øllgaard \& Windisch (1987), associados às informações obtidas no campo.

\section{Resultados}

No Parque Nacional do Itatiaia, reconheceram-se 23 espécies e uma variedade de Lycopodiaceae, totalizando $43 \%$ das espécies citadas para o país e $72 \%$, para o estado do Rio de Janeiro. Estes dados demonstram a importância da conservação da área à manutenção da diversidade da família.

Huperzia foi o gênero mais representativo, com 15 espécies. Lycopodiella apresentou quatro espécies e uma variedade e Lycopodium, quatro espécies.

Chave para identificação dos gêneros de Lycopodiaceae no Parque Nacional do Itatiaia

1. Caule ascendente, ereto ou pendente, às vezes decumbente, ramificado isotomicamente; esporofilos modificados ou não, persistentes, não reunidos em estróbilos 1. Huperzia

1. Caule reptante, longo-reptante, sarmentoso ou rizomatoso, ramificado anisotomicamente; esporofilos sempre modificados, efêmeros, reunidos em estróbilos

2. Caule primário com ramo secundário inserido dorsalmente; estróbilos sempre sésseis, eretos ou pendentes; esporângios anisovalvados

2. Lycopodiella

2. Caule primário com ramo secundário inserido lateralmente; estróbilos sésseis ou pedunculados, sempre eretos; esporângios isovalvados

3.Lycopodium

1. Huperzia Bernh., J. Bot. (Schrader) 1800 (2): 126. 1801. Lectótipo: Lycopodium selago L., Sp. Pl. 1102. 1753

(Huperzia selago (L.) Bernh. ex Schrank \& Mart., designado por Rothmaler, Feddes Repert. Spec. Nov. Regni Veg. 54: 59. 1944).

Esporófitos epífitos, terrestres ou rupícolas. Caule ascendente, ereto ou pendente, às vezes decumbente, ramificado isotomicamente, glabro, homoblástico. Raízes adventícias emergindo num tufo basal, às vezes partindo perpendicularmente ao caule quando decumbente. Microfilos homófilos a heterófilos, isófilos. Esporofilos modificados ou não, persistentes, verdes após a deiscência dos esporângios, não reunidos em estróbilos. Esporângios axilares, subglobosos a reniformes, isovalvados. Gametófitos subterrâneos, micoparasíticos.

Huperzia é um gênero cosmopolita, ocorrendo em regiões tropicais, temperadas, no ártico e nos Alpes (Øllgaard 1987).

Dos três gêneros de Lycopodiaceae registrados para os Neotrópicos, Huperzia é o maior com ca. de 150 espécies, sendo 38 destas citadas para o Brasil (Øllgaard $1987 ; 1990 ; 1992 ; 1995 ; 1996)$. Contabilizaram-se, para o Parque Nacional do Itatiaia, 15 espécies preferencialmente epífitas, correspondentes a 39\% das Huperzia citadas para o país, e $65 \%$ das espécies ocorrentes para o Rio de Janeiro.

Chave para identificação das espécies de Huperzia no Parque Nacional do Itatiaia

1. Caule pendente; microfilos com margem inteira

2. Microfilos expandidos presentes ou não na porção proximal do caule; microfilos adpressos, triangular-ovados

3. Caule arredondado-angular (incluindo os microfilos) na porção proximal a agudo-quadrangular (incluindo os microfilos) nas porções mediana e distal; microfilos adpressos e ápice dos esporofilos não conduplicado

1.8. H. hexasticha

3. Caule quadrangular (incluindo os microfilos) em toda sua extensão; microfilos adpressos e ápice dos esporofilos conduplicado

1.13. H. quadrifariata

2. Microfilos expandidos sempre ausentes na porção proximal do caule; microfilos ascendentes a patentes, aciculares a lanceolados.

4. Microfilos alterno-espiralados; esporofilos opostos e cruzados

5. Esporófitos epífitos; caule 0,7-1,5 mm diâm. (incluindo os esporofilos) na porção distal, sempre verdepardacento.

5. Esporófitos rupícolas; caule 1,5-2,3 mm diâm. (incluindo os esporofilos) na porção distal, vermelho (quando fresco) a levemente esverdeado (quando seco) 1.6. H. erythrocaulon

4. Microfilos e esporofilos alterno-verticilados ou irregularmente verticilados. 
6. Microfilos aciculares ou lineares, quatro a cinco microfilos por verticilo.

7. Microfilos aciculares, cartáceos, 0,2-0,4 $\mathrm{mm}$ larg

7. Microfilos lineares, membranáceos, 0,4-0,5 mm larg.

8. Microfilos com venação pouco proeminente; dois a oito verticilos de esporofilos por porção fértil

8. Microfilos com venação proeminente castanho-esverdeada (quando fesco) a castanha (quando seco); oito ou mais verticilos de esporofilos por porção fértil. 1.10. H. mollicoma

6. Microfilos linear-lanceolados ou lanceolados, três microfilos por verticilo.

9. Microfilos linear-lanceolados, ápice longo-acuminado, 0,7-1 mm larg.

1.7.H. heterocarpon

9. Microfilos lanceolados, ápice acuminado, 1-2 mm larg.

10. Microfilos com ápice conduplicado, margem esbranquiçada, 3,5-8 mm comp.

1.9. H. loefgreniana

10. Microfilos com ápice não conduplicado, margem com coloração uniforme, 8-20 mm comp.

1.15. H. silveirae

1. Caule ascendente a ereto, às vezes decumbente; microfilos com margem inteira, sinuosa ou denticulada.

11. Microfilos com margem denticulada

12. Caule uma a duas vezes dicotômico; microfilos ascendentes, raro patentes, linearlanceolados. 1.4. H. christii

12. Caule duas a cinco vezes dicotômico; microfilos reflexos, raro ascendentes, linearsubulados......

1.14. H. reflexa

11. Microfilos com margem inteira ou sinuosa

13. Microfilos lanceolados, margem sinuosa

1.2. H. badiniana

13. Microfilos lineares, margem inteira

14. Caule duas a três vezes dicotômico, nitidamente visível entre os verticilos de microfilos e esporofilos

1.11. H. nuda

14. Caule quatro a seis vezes dicotômico, não visível entre os verticilos de microfilos e esporofilos 1.12. H.pungentifolia

1.1. Huperzia acerosa (Sw.) Holub, Folia Geobot. Phytotax. 20: 70. 1985. Lycopodium acerosum Sw., Fl. Ind. Occid. 3: 1575. 1806. Tipo: Ilustração de Plumier, Traité Foug. Amér., t. 166, f. B, 1705 (designado por Proctor, Fl. Lesser Antilles 2: 25. 1977).

Fig. 1-3

Esporófitos epífitos, terrestres ou rupícolas. Caule pendente, cinco a vinte vezes dicotômico, 15,5-27 cm compr., 2,5-4 mm diâm. (incluindo os microfilos) nas porções proximal e mediana, 1,5-6 mm diâm. (incluindo os microfilos) na porção distal, ca. $1 \mathrm{~mm}$ diâm. (excluindo os microfilos) na porção proximal, diminuindo seu diâmetro para $(0,3-) 0,5 \mathrm{~mm}$ na porção distal, verde a verde-pardacento, com raízes adventícias emergindo num tufo basal. Microfilos expandidos sempre ausentes na porção proximal do caule. Microfilos ascendentes, alterno-verticilados, aciculares, ápice acuminado, margem inteira, venação pouco proeminente, cartáceos, verdes, cinco microfilos por verticilo, (2-)3-5x0,2-0,4 mm. Esporofilos distribuídos nas porções mediana e distal do caule, semelhantes aos microfilos, base ligeiramente mais alargada na inserção do esporângio, quatro a cinco esporofilos por verticilo, seis a 12 verticilos por porção fértil, $0,2-2,1 \mathrm{~cm}$ de porções estéreis entre as férteis, (2-)3-4x0,2-0,5 mm. Esporângios axilares, reniformes, amarelos a esbranquiçados, 0,5-0,8x0,7-1 mm.
Material selecionado: BRASIL. Minas Gerais: Bocaina de Minas, Alto dos Brejos, 2000 m, 27/X/2006, Ramos et al. 71 (RB). Rio de Janeiro: Itatiaia, Base das Agulhas Negras, ca. de 2600 m, 8/VIII/2006, Ramos et al. 60 (RB); Caminho para Prateleiras, 2400 m, 1/VIII/1973, Barcia 656 (R); Estrada para o Planalto, 13/VII/2006, Ramos et al. 43 (RB); Lagoa do Altar, $2500 \mathrm{~m}, 11 / \mathrm{VI} / 2005$, Condack \& Cortines 408 (RB); Lote 21, 760 m, 12/VII/2006, Ramos et al. 34 (RB); Proximidades da Ponte do Maromba, margem do Rio Campo Belo, 1050 m, 29/IX/1995, Braga et al. 2869 (RB).

A espécie distribui-se por todo o Norte da América Tropical (Øllgaard \& Windisch 1987). No Brasil, ocorre nos estados da Bahia, Minas Gerais, Rio de Janeiro, São Paulo, Paraná, Santa Catarina e Rio Grande do Sul.

Encontrada em florestas montanas e matas nebulares entre 300-2600 m, sendo as menores altitudes na parte sul da área de ocorrência (Øllgaard \& Windisch 1987). No PNI, os espécimes de Huperzia acerosa são preferencialmente epífitos, crescendo a 0,5-2 m do solo. Foram observados no interior de matas, em fendas de rochas, à beira das estradas ou trilhas, em ambiente sombreado e úmido ou ensolarado, em altitudes variando de $760 \mathrm{~m}$ a $2600 \mathrm{~m}$.

1.2. Huperzia badiniana B. Øllg. \& P. G. Windisch, Bradea 5(1): 7, f. 1A. 1987. Tipo: Brasil, Minas Gerais, Serra do 
Caparaó, ca. de 2570 m, 08/II/1987, Windisch et al. 4971

(holótipo HB!; isótipos AAU, GH, SP!, SPF).

Fig. 4

Esporófitos terrestres. Caule ascendente a ereto, às vezes decumbente, simples a duas vezes dicotômico, 6,5-34 cm compr., 10-20 mm diâm. (incluindo os microfilos) nas porções proximal e mediana, $8-13 \mathrm{~mm}$ diâm. (incluindo os microfilos) na porção distal, 2-3,5 mm diâm. (excluindo os microfilos) nas porções proximal e mediana, 2-3 mm diâm. (excluindo os microfilos) na porção distal, castanho a verde-oliva, com raízes adventícias emergindo num tufo basal, às vezes partindo perpendicularmente ao caule quando decumbente. Microfilos ascendentes, raro patentes, alternoverticilados, lanceolados, ápice agudo, margem sinuosa, venação pouco proeminente, subcoriáceos, verde-olivas a amarelados, quatro a seis microfilos por verticilo, 8-11 x1,4-2 $\mathrm{mm}$. Esporofilos distribuídos da porção mediana a distal do caule, semelhantes aos microfilos, base ligeiramente arredondada na inserção do esporângio, quatro a seis esporofilos por verticilo, 6-10x1,4-2 mm. Esporângios axilares, reniformes, amarelos ou verdes, 0,8-1,5x1,5-2 mm.

Material selecionado: BRASIL. Rio de Janeiro: Itatiaia, Abrigo Rebouças, 2386 m, 13/VII/2006, Ramos et al. 48 (RB); Agulhas Negras, 2650 m, 9/VIII/2006, Condack 524 (RB); Caminho Rebouças-Prateleiras, 2407 m, 13/VII/2006, Ramos et al. 47 (RB); Planalto, 2300 m, 21/XI/1948, Brade 18893 (RB).

A espécie é endêmica do Brasil, ocorrendo nos estados de Minas Gerais, Rio de Janeiro e Santa Catarina.

$\mathrm{Na}$ área de estudo, Huperzia badianiana cresce às margens de trilhas ou em paredões de rocha, em locais úmidos e ensolarados, podendo ser encontrada em altitudes que variam de $2100 \mathrm{~m}$ a $2650 \mathrm{~m}$.

Huperzia badiniana é reconhecida, principalmente, pelos microfilos e esporofilos lanceolados, com margem sinuosa e subcoriáceos. Pode ser confundida com $H$. treitubensis (Silveira) B. Øllg., espécie endêmica de algumas montanhas no estado de Minas Gerais (Øllgaard \& Windisch 1987), a qual não foi registrada para a área de estudo. Todavia, $H$. treitubensis apresenta microfilos e esporofilos aciculares, às vezes carenados, com margem inteira e de consistência coriácea.

1.3. Huperzia biformis (Hook.) Holub, Folia Geobot. Phytotax. 20: 71. 1985. Lycopodium biforme Hook., Icon. Pl. 3: t. 228. 1839. Tipo: Brazil, Organ Mountains, 2nd. Fern Coll., Gardner 80 (holótipo K; isótipos BM, P).

\section{Fig. 5-6}

Esporófitos epífitos. Caule pendente, às vezes levemente flexuoso, duas a dez vezes dicotômico, ca. de $29-48 \mathrm{~cm}$ compr., 12-27,5 mm diâm. (incluindo os microfilos) nas porções proximal e mediana, $0,7-1,5 \mathrm{~mm}$ diâm. (incluindo os esporofilos) na porção distal, $0,5-1 \mathrm{~mm}$ diâm. (excluindo os microfilos) da porção proximal a distal, sempre verdepardacento, com raízes adventícias emergindo num tufo basal. Microfilos expandidos sempre ausentes na porção proximal do caule. Microfilos patentes, às vezes com ápice voltado para cima, alterno-espiralados, espaçados, linearlanceolados a lanceolados, ápice cuneado, margem inteira, venação proeminente, herbáceos, verdes, 6-15x1-2 mm. Esporofilos distribuídos na porção distal do caule, raro na porção mediana, ascendentes, opostos e cruzados, obovados, ápice acuminado, às vezes arredondado a obtuso, margem inteira, venação pouco proeminente, herbáceos, verdes a verde-escuros, ramos férteis de uma a seis vezes dicotômico, 1,5-10 cm compr., 1,3-1,9 cm de porções estéreis entre as férteis, 1-2x0,7-1,3 mm. Esporângios axilares, reniformes, amarelos a levemente esverdeados, 0,3-0,8x0,7-1 mm.

Material selecionado: BRASIL. Minas Gerais: Bocaina de Minas, Trilha para o Alto do Brejos, $22^{\circ} 17^{\prime} 43^{\prime \prime} \mathrm{S}$, 44³6’38”'W, 1700 m, 31/V/2006, Ramos et al. 28 (RB). Rio de Janeiro: Itatiaia, Macieiras, 1800 m, 26/II/1945, Brade 17518 (RB); Mata atrás do Abrigo Massena, 19/VIII/2004, Sylvestre \& Condack 1778 (RB).

É uma espécie endêmica do Brasil, ocorrendo nos estados de Minas Gerais, Espírito Santo, Rio de Janeiro, São Paulo, Paraná e Santa Catarina.

Habita locais protegidos em florestas montanas úmidas, 850-2100 m (Øllgaard \& Windisch 1987). Esta espécie epífita obrigatória foi encontrada, no PNI, crescendo a 1 $\mathrm{m}$ do solo, no interior de mata, raro às margens de trilhas, em ambiente úmido e sombreado, em altitudes entre 1700 $\mathrm{m}$ e $2000 \mathrm{~m}$.

Huperzia biformis é reconhecida pelo hábito epífito no interior de mata, esporofilos diferentes dos microfilos (heterofilia) e caule de coloração verde-pardacenta.

1.4. Huperzia christii (Silveira) Holub, Folia Geobot. Phytotax. 20: 71. 1985. Lycopodium christii Silveira, Bol. Comm. Geogr. Geol. Minas Geraes 2, 5: 117, t. 1. 1898. Tipo: Brasil, Minas Gerais, Silveira 2609 (holótipo $\mathrm{P}$; isótipo $\mathrm{RB}$ ).

Fig. 7

Esporófitos terrestres. Caule ascendente a ereto, uma a duas vezes dicotômico, 9,5-23 cm compr., 10-19 mm diâm. (incluindo os microfilos) nas porções proximal e mediana, 13-18 mm diâm. (incluindo os microfilos) na porção distal, ca. $2 \mathrm{~mm}$ diâm. (excluindo os microfilos) nas porções proximal e mediana, 1,5-2 mm diâm. (excluindo os microfilos) na porção distal, verde-oliva a castanho (proximal), com raízes adventícias emergindo num tufo basal. Microfilos ascendentes, raro patentes, alterno-verticilados, linearlanceolados, ápice acuminado, margem denticulada, venação proeminente, membranáceos, verde-olivas, quatro microfilos por verticilo, 5-10x1-1,5 mm. Esporofilos distribuídos da porção mediana a distal do caule ou nestas separadamente, às vezes com porções estéreis ao final do ramo, semelhantes aos microfilos, venação pouco proeminente, base arredondada na inserção do esporângio, quatro esporofilos por verticilo, oito 


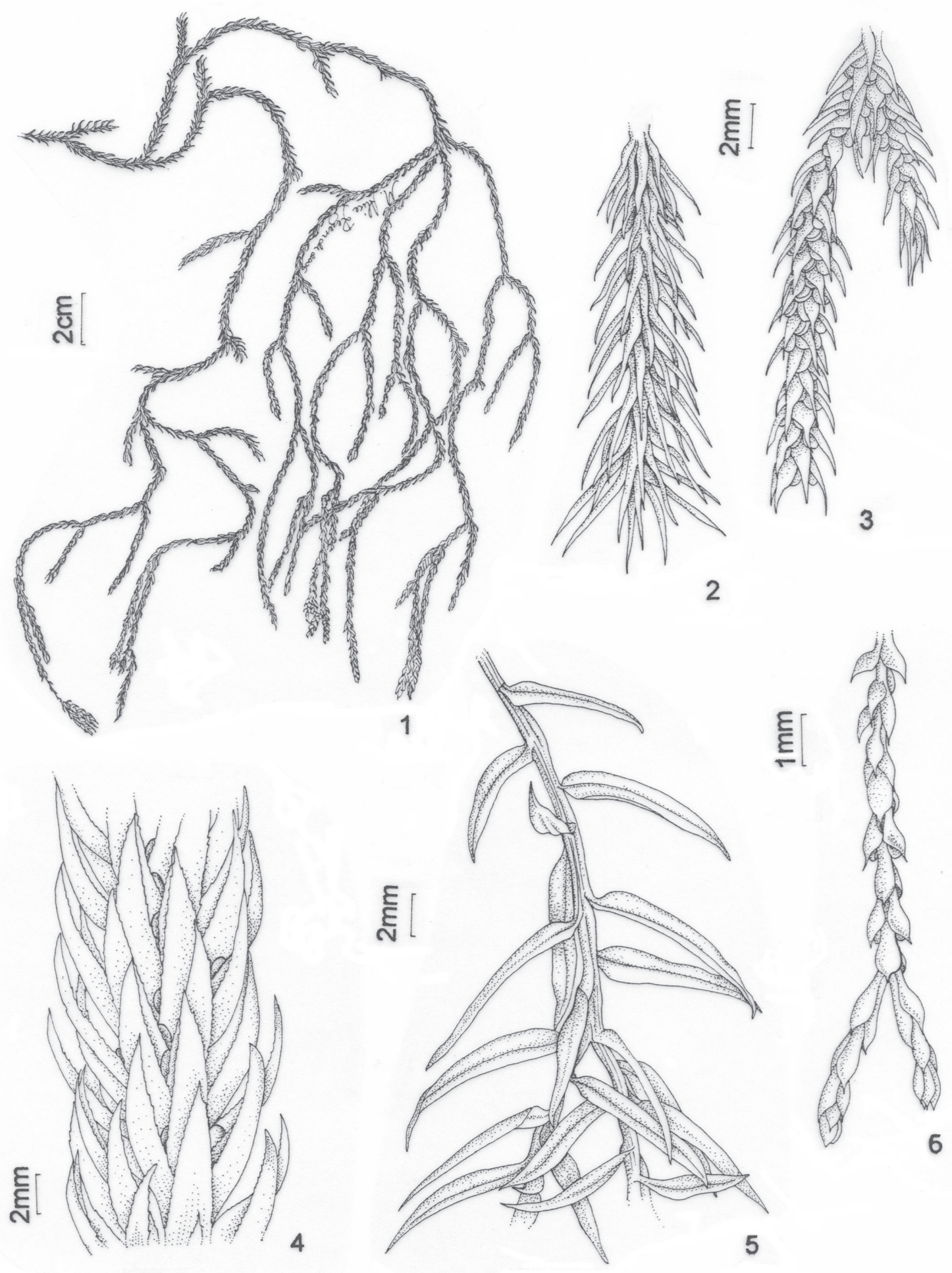

Figuras 1-3. Huperzia acerosa (Sw.) Holub. 1. Hábito. 2. Porção proximal do caule evidenciando os microfilos aciculares. 3. Porção distal do caule mostrando os esporofilos (Ramos et al. 43). Figura 4. Huperzia badiniana B. Øllg. \& P. G. Windisch - Porção mediana do caule evidenciando os microfilos e os esporofilos lanceolados, com margem sinuosa (Ramos et al. 47). Figuras 5-6. Huperzia biformis (Hook.) Holub. 5. Porção mediana do caule mostrando os microfilos alternoespiralados. 6. Porção distal do ramo fértil mostrando os esporofilos opostos e cruzados (Ramos et al. 28). 
ou mais verticilos por porção fértil, 1,5-1,8 cm de porções estéreis entre as férteis, 6-8(-9)x1-1,3(-1,5) mm. Esporângios axilares, reniformes, amarelos, 0,7-1,2x1,3-2 mm.

Material selecionado: BRASIL. Minas Gerais: Bocaina de Minas, Alto dos Brejos, 1900 m, 31/V/2006, Condack \& Ramos 459 (RB). Rio de Janeiro: Itatiaia, Base da Agulhas Negras, ca. de 2500 m, 8/VIII/2006, Ramos et al. 57 (RB); Caminho Massena-Rebouças, 10/VIII/2006, Ramos et al. 68 (RB); Pedra do Eco, 2400 m, III/1937, Brade 15724 (RB); Trilha do Hotel Simon para os Três Picos, 1250 m, 29/IX/2005, Sylvestre et al. 1852 (RB).

A espécie é endêmica do Brasil, ocorrendo nos estados de Pernambuco, Minas Gerais, Rio de Janeiro, São Paulo e Paraná.

Huperzia christii é encontrada em locais abertos, de 100 m a 1850 m (Øllgaard \& Windisch 1987). No PNI, localizase em barrancos ao longo de trilhas, em ambiente úmido, em altitudes que variam de $1250 \mathrm{~m}$ a $2500 \mathrm{~m}$.

No campo, Huperzia christii pode ser confundida com $H$. badiniana. No entanto, $H$. badiniana apresenta microfilos e esporofilos lanceolados, de ápice agudo, com margem sinuosa e consistência subcoriácea.

1.5. Huperzia comans (Nessel) B. Øllg. \& P. G. Windisch, Bradea 5(1): 8. 1987. Urostachys comans Herter ex Nessel, Arch. Bot. São Paulo 1: 400. 1927., nom. nov. para Lycopodium comans Christ, In Schwacke, Plantas Novas Mineiras 2: 40.1900 (non Hook. f. 1844.). Tipo: Brasil, Serra de Itatiaia, 2100 m, III/1894, Ule 255, 3537 (holótipo P; isótipos HBG, R!).

Fig. 8-9

Esporófitos epífitos. Caule pendente, cinco a nove vezes dicotômico, 25,5-37 cm compr., 2-8 mm diâm. (incluindo os microfilos) nas porções proximal, mediana e distal, 0,5-0,8 mm diâm. (excluindo os microfilos) na porção proximal, diminuindo ou mantendo seu diâmetro para ca. 0,5 mm na porção distal, verde-pardacento, com raízes adventícias emergindo num tufo basal. Microfilos expandidos sempre ausentes na porção proximal do caule. Microfilos ascendentes, alterno-verticilados, lineares, ápice longo-acuminado, margem inteira, venação pouco proeminente, membranáceos, verdes, quatro a cinco microfilos por verticilo, 3,5-8(-10) $\mathrm{x} 0,4-0,5 \mathrm{~mm}$. Esporofilos distribuídos nas porções mediana e distal do caule, às vezes com porções estéreis ao final do ramo, semelhantes aos microfilos, base arredondada a obtusa na inserção do esporângio, três a quatro esporofilos por verticilo, dois a oito verticilos por porção fértil, 0,5-3,8 $\mathrm{cm}$ de porções estéreis entre as férteis, 3,5-5x0,4 mm. Esporângios axilares, reniformes, amarelos a esbranquiçados, 0,5-0,7x0,7-1 mm.

Material selecionado: BRASIL. Minas Gerais: Bocaina de Minas, Alto dos Brejos, 1800 m, 30/III/2005, Condack 322 (RB). Rio de Janeiro: Itatiaia, Caminho para a nascente, depois da mata de frente ao Abrigo Massena, 18/ VIII/2004, Sylvestre \& Condack 1766 (RB); Estrada para o
Planalto, $2281 \mathrm{~m}, 13 / \mathrm{VII} / 2006$, Ramos et al. 45 (RB); Retiro, 23/V/1902, Dusén 149 (R).

A espécie é endêmica do Brasil, ocorrendo nos estados de Minas Gerais, Rio de Janeiro, São Paulo e Paraná.

Huperzia comans é encontrada em florestas altomontanas e matas nebulares, entre $1200-2400 \mathrm{~m}$, sendo as menores altitudes observadas nos estados sulinos (Øllgaard $\&$ Windisch 1987). No PNI, localiza-se no interior da mata, à margem de trilhas ou próxima aos rios, crescendo ca. 2 $\mathrm{m}$ do solo, em altitudes que variam de $1800 \mathrm{~m}$ a $2300 \mathrm{~m}$.

1.6. Huperzia erythrocaulon (Fée) Holub, Folia Geobot. Phytotax. 20: 72. 1985. Lycopodium erythrocaulon Fée, Cryptog. Vasc. Brésil 2: 95, t. 106, f. 2. 1872-73. Tipo: "Brasilia fluminensi", Glaziou 5221 (holótipo P; isótipos B, C, K, S).

Fig. 10-12

Esporófitos rupícolas. Caule pendente, às vezes levemente flexuoso, duas a oito vezes dicotômico, ca. 12-21 cm compr., 1-2,5 mm diâm. (incluindo os microfilos) nas porções proximal e mediana, 1,5-2,3 mm diâm. (incluindo os esporofilos) na porção distal, 0,5-1 mm diâm. (excluindo os microfilos) da porção basal a distal, vermelho (quando fresco) a levemente esverdeado (quando seco), com raízes adventícias emergindo num tufo basal. Microfilos expandidos sempre ausentes na porção proximal do caule. Microfilos ascendentes a patentes, alterno-espiralados, espaçados, linear-lanceolados a lanceolados, ápice cuneado a acuminado, margem inteira, venação proeminente, cartáceos, verdes, às vezes com porções avermelhadas (quando fresco), 5,5-11,5x1-2 mm. Esporofilos distribuídos na porção distal do caule, raro na porção mediana, ascendentes, opostos e cruzados, ovados, ápice obtuso a acuminado, margem inteira, subcoriáceos, venação proeminente, verdes, às vezes com porções avermelhadas (quando fresco), ramos férteis de uma a quatro vezes dicotômico, 1,5-8 cm compr., ca. $1 \mathrm{~cm}$ de porções estéreis entre as férteis, 1,52,2x1,0-1,5 mm. Esporângios axilares, reniformes, amarelos a levemente esverdeados, 0,5-1x1-1,3 mm.

Material selecionado: BRASIL. Rio de Janeiro: Itatiaia, Agulhas Negras, 2700 m, 8/VIII/2006, Ramos et al. 58 (RB); Pedra do Eco, 7/VIII/2006, Ramos et al. 52 (RB); Prateleiras, proximidades da Pedra da Maçã e Pedra da Tartaruga, 7/ VIII/2006, Ramos et al. 50 (RB); Pedra do Altar, 2665 m, 11/VI/2005, Condack \& Cortines 403 (RB).

Esta espécie é endêmica do Brasil, ocorrendo nos estados de Minas Gerais e Rio de Janeiro.

Huperzia erythrocaulon é observada em áreas rupestres abertas restritas aos campos de altitude, entre 1900-2400 m (Øllgaard \& Windisch 1987). Na área de estudo, localizaramse os representantes desta espécie na base ou em fendas de rochas, em ambiente ensolarado, em altitudes que variam de $2300 \mathrm{~m}$ a $2700 \mathrm{~m}$.

Como em Huperzia biformis, H. erythrocaulon apresenta os esporofilos diferentes dos microfilos (heterofilia). Toda- 

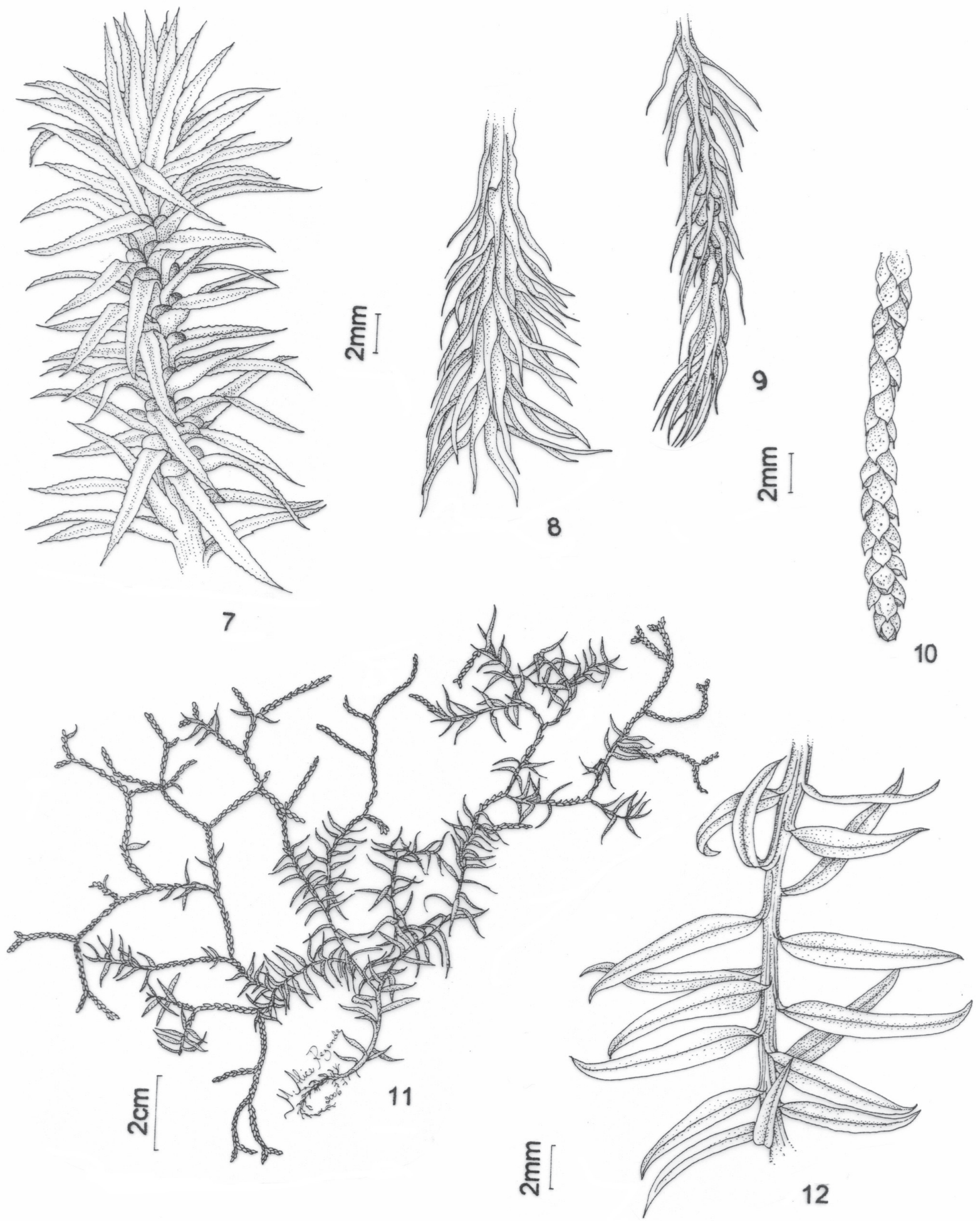

Figura 7. Huperzia christii (Silveira) Holub. Porção distal do caule evidenciando os microfilos e os esporofilos linear-lanceolados, com margem denticulada (Ramos et al. 68). Figuras 8-9. Huperzia comans (Nessel) B. Øllg. \& P. G. Windisch. 8. Porção proximal do caule evidenciando os microfilos lineares. 9. Porção distal evidenciando os verticilos de esporofilos (Ramos et al. 45). Figuras 10-12. Huperzia erythrocaulon (Fée) Holub. 10. Porção distal do ramo fértil mostrando os esporofilos opostos e cruzados. 11. Hábito. 12. Porção mediana do caule mostrando os microfilos alterno-espiralados (Ramos et al. 50). 
via, H. biformis é uma espécie epífita obrigatória e possui caule com diâmetro (incluindo os esporofilos) menor na porção distal. O caule de $H$. erythrocaulon possui coloração vermelha na base, a qual pode se esmaecer em direção à porção distal. Este caráter, algumas vezes, não pôde ser observado no material seco, pois a coloração vermelha se perde ao longo do tempo nos materiais herborizados.

1.7. Huperzia heterocarpon (Fée) Holub, Folia Geobot. Phytotax. 20: 73. 1985. Lycopodium heterocarpon Fée, Cryptog. Vasc. Brésil 2: 93. 1872-73. Tipo: "Brasilia fluminensi”, Glaziou 5636 (holótipo P; isótipos C, K).

Fig. 13-14

Esporófitos epífitos. Caule pendente, quatro a sete vezes dicotômico, 45-50 cm compr., 14-22,5 mm diâm. (incluindo os microfilos) nas porções proximal e mediana, 4-15 mm diâm. (incluindo os microfilos) na porção distal, ca. 1,5 mm diâm. (excluindo os microfilos) na porção proximal, diminuindo para $0,5 \mathrm{~mm}$ na porção distal, verde-claro, com raízes adventícias emergindo num tufo basal. Microfilos expandidos sempre ausentes na porção proximal do caule. Microfilos patentes, alternoverticilados, linear-lanceolados, ápice longo-acuminado, margem inteira, venação pouco proeminente, canaliculada e esbranquiçada na base, cartáceos, verdes, três microfilos por verticilo, 11,5-16x0,7-1 mm. Esporofilos localizados da porção mediana a distal do caule, semelhantes aos microfilos, base distintamente mais alargada na inserção do esporângio, às vezes reduzidos gradualmente em direção à porção distal do caule, herbáceos, três esporofilos por verticilo, 3-11,5x0,4-1 mm. Esporângios axilares, reniformes, amarelos a verde-claros, 1-1,5x1,3-2 mm.

Material selecionado: BRASIL. Rio de Janeiro: Itatiaia, Caminho para Prateleiras, 2400 m, 1/VIII/1975, Barcia 631 (R); Lote 21, 760 m, 12/VII/2006, Ramos et al. 33 (RB); Margem do Rio Campo Belo, entre o Lago Azul e o rio Taquaral, 740 m, 28/IX/2005, Sylvestre et al. 1813 (RB); Trilha para o Itaporani, 1/VI/2006, Ramos et al. 31 (RB); Trilha para os Três Picos, 1300 m, 30/V/2006, Ramos et al. 20 (RB).

A espécie é encontrada na Argentina (Missiones) e no Brasil (Pernambuco, Minas Gerais, Espírito Santo, Rio de Janeiro, São Paulo, Paraná, Santa Catarina e Rio Grande do Sul).

Huperzia heterocarpon ocorre em florestas montanas e em formações de araucárias, de 500 m a 1600 m (Øllgaard \& Windisch 1987). Espécie epífita obrigatória, cresce, no PNI, ca. 1-2 $\mathrm{m}$ do solo, localizada às margens de trilhas ou próxima à córregos, em altitudes que variam de 740 a $2400 \mathrm{~m}$.

A espécie é reconhecida principalmente pelo hábito epífito, microfilos e esporofilos linear-lanceolados, com ápice longo-acuminado e venação esbranquiçada na base das folhas.

1.8. Huperzia hexasticha B. Øllg. \& P. G. Windisch, Bradea 5(1): 11, f. 2. 1987. Tipo: Brasil, São Paulo, Campos do
Jordão, estrada a São José dos Alpes, $12 \mathrm{~km}$ do Horto Florestal, ca. $1850 \mathrm{~m}$, Windisch et al. 4995 (holótipo HB!; isótipos AAU, GH, SP!, SPF).

Fig. 15-16

Esporófitos epífitos ou terrestres. Caule pendente, arredondado-angular (incluindo os microfilos) na porção proximal a agudo-quadrangular (incluindo os microfilos) nas porções mediana e distal, quatro a nove vezes dicotômico, 25-60 cm compr., 1,5-3 mm diâm. (incluindo os microfilos) nas porções proximal e mediana, 1-2 mm diâm. (incluindo os microfilos) na porção distal, 1-2,5 mm diâm. (excluindo os microfilos) nas porções proximal e mediana, $0,5-1 \mathrm{~mm}$ diâm. (excluindo os microfilos) na porção distal, castanho (proximal) a verde-oliva, com raízes adventícias emergindo num tufo basal. Microfilos expandidos presentes ou não na porção proximal do caule, patentes, alterno-verticilados, oblongos, ápice agudo a obtuso, margem inteira, venação pouco proeminente, cartáceos, verde-olivas a pardacentos, três microfilos por verticilo, $5-15 \times 1-2 \mathrm{~mm}$. Microfilos adpressos localizados em toda a extensão do caule, opostos ou alterno-verticilados, imbricados, triangular-ovados, ápice agudo não conduplicado, margem inteira, venação pouco proeminente, coriáceos, verde-olivas, três microfilos por verticilo (proximal) a dois microfilos opostos (mediana e distal), 1,5-3x1,3-2 mm. Esporofilos localizados na porção distal do caule, às vezes com porções estéreis ao final do ramo, semelhantes aos microfilos adpressos, dois esporofilos ascendentes, opostos, imbricados, quatro ou mais pares de esporofilos opostos por porção fértil, $0,2-1,2 \mathrm{~cm}$ de porções estéreis entre as férteis, 1-1,5x0,8-1(-1,4) mm. Esporângios axilares, subglobosos, amarelos a amarelo-claros, 0,7$1,1 \times 0,8-1,3 \mathrm{~mm}$.

Material selecionado: BRASIL. Minas Gerais: Bocaina de Minas, Alto dos Brejos, 1800 m, 27/X/2006, Ramos et al. 75 (RB). Rio de Janeiro: Itatiaia, Caminho para Pedra Assentada, 2400 m, 20/VIII/2005, Condack 425 (RB); Prateleiras, proximidades da Pedra da Maçã e Pedra da Tartaruga, 7/VIII/2006, Ramos et al. 51 (RB).

Huperzia hexasticha é endêmica do Brasil, ocorrendo nos estados de Minas Gerais, Rio de Janeiro, São Paulo, Paraná, Santa Catarina e Rio Grande do Sul.

A espécie é encontrada em florestas nebulares, entre 1000 m e 2400 m (Øllgaard \& Windisch 1987). No PNI, ocorre em bordo de trilha, em fendas de rocha ou no interior de mata, em altitudes que variam de $2000 \mathrm{~m}$ a $2400 \mathrm{~m}$. Quando epífita, cresce de 0,3-2 m do solo.

Nos espécimes de Huperzia hexasticha, os microfilos expandidos nem sempre são observados, pois se fragmentam facilmente ao longo do tempo, principalmente em ambientes secos.

1.9. Huperzia loefgreniana (Silveira) B. Øllg. \& P. G. Windisch, Bradea 5(1): 13. 1987. Lycopodium loefgrenianum Silveira, Flora e Serras Mineiras 78, t. 30. 1908. Tipo: Brasil, São Paulo, in silvis de arboribus pendens prope 

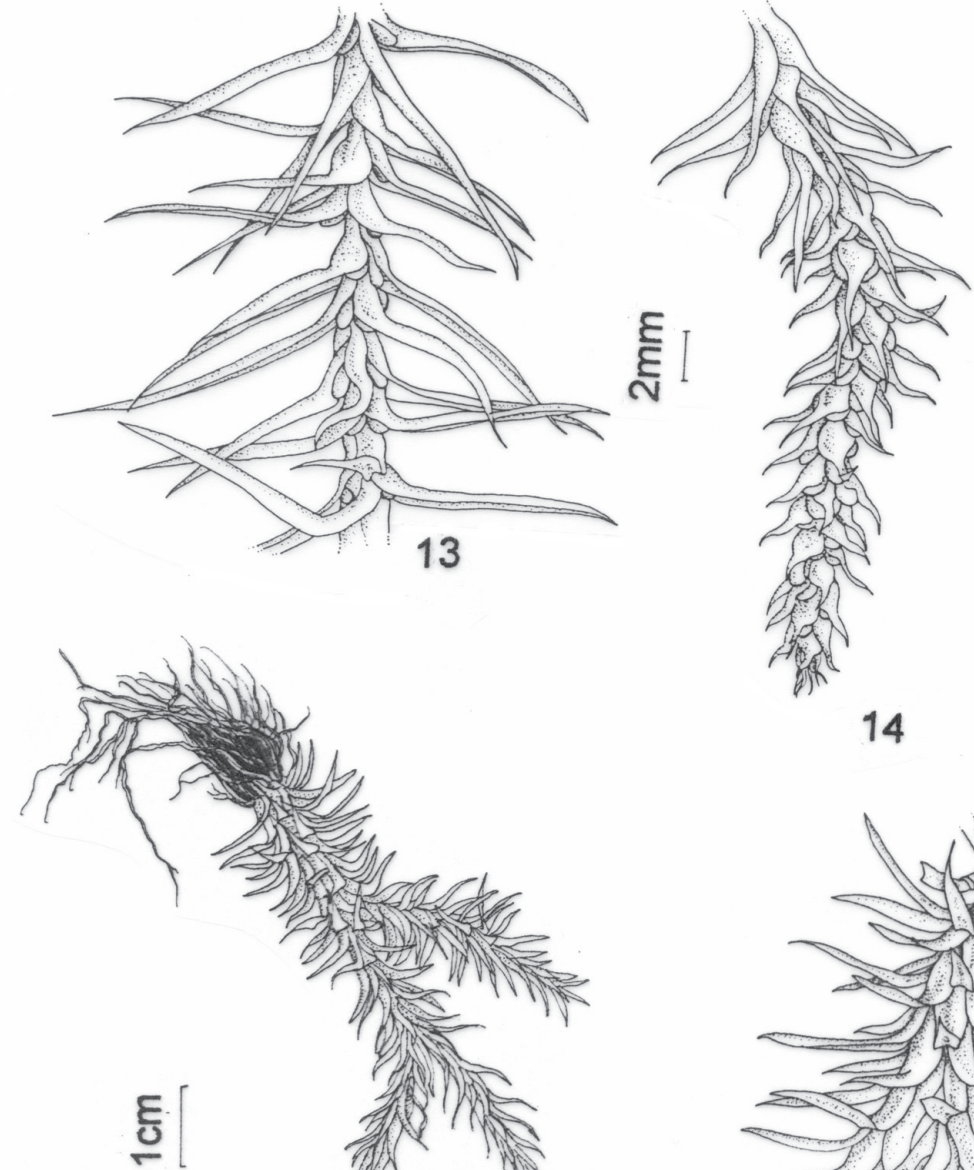

14
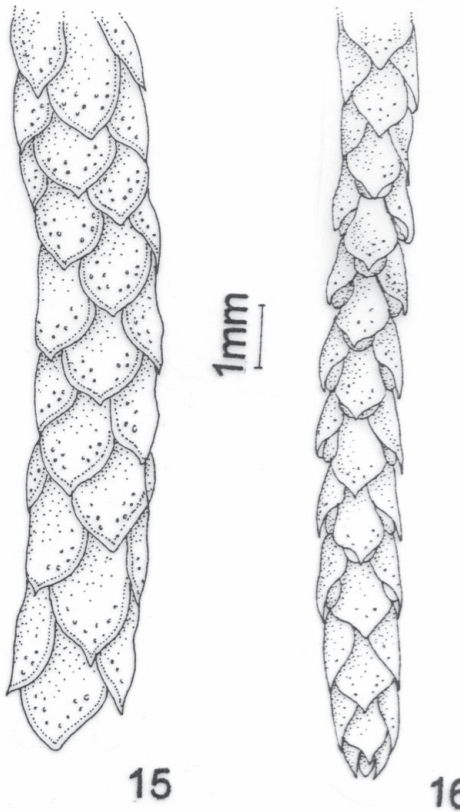

16

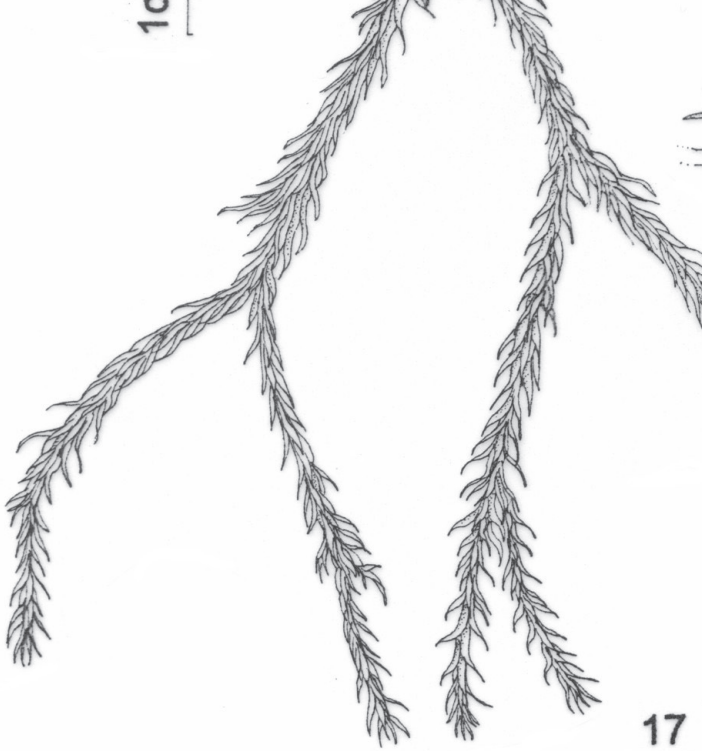

Figuras 13-14. Huperzia heterocarpon (Fée) Holub. 13. Porção mediana do caule mostrando os esporofilos linear-lanceolados. 14. Porção distal do caule evidenciando a heterofilia gradual (Ramos et al. 20). Figuras 15-16. Huperzia hexasticha B. Øllg. \& P. G. Windisch. 15. Porção proximal do caule mostrando os microfilos adpressos. 16. Porção distal do ramo fértil (Ramos et al. 51). Figuras 17-19. Huperzia loefgreniana (Silveira) B. Øllg. \& P. G. Windisch. 17. Hábito. 18. Porção proximal com microfilos lanceolados. 19. Porção mediana mostrando os esporofilos (Sylvestre et al. 1854). 
Bocaina, IV/1894, Löfgren s.n., In Herb. Silveira n. 197 (holótipo R 154768; fragmento de isótipo BONN-herb. Nessel 368a).

Fig. 17-19

Esporófitos epífitos. Caule pendente, quatro a seis vezes dicotômico, 27-30 cm compr., 4-14 mm diâm. (incluindo os microfilos) nas porções proximal e mediana, 3-5 mm diâm. (incluindo os microfilos) na porção distal, 0,9-2 mm diâm. (excluindo os microfilos) nas porções proximal e mediana, 0,7-0,8 mm diâm. (excluindo os microfilos) na porção distal, verde-oliva, com raízes adventícias emergindo num tufo basal. Microfilos expandidos sempre ausentes na porção proximal do caule. Microfilos ascendentes a patentes, irregularmente verticilados, lanceolados, às vezes canaliculados, ápice acuminado e conduplicado, margem inteira e esbranquiçada, venação proeminente, cartáceos, verde-escuros, três microfilos por verticilo, 3,5-8x1-1,5 mm. Esporofilos localizados nas porções mediana e distal do caule, semelhantes aos microfilos, base alargada na inserção do esporângio, às vezes reduzidos gradualmente em direção à porção distal do caule, sete ou mais verticilos por porção fértil, $0,3-3,5 \mathrm{~cm}$ de porções estéreis entre as férteis, 3-6x0,5-1 mm. Esporângios axilares, reniformes, amarelo-claros, 0,8-1x1,1-1,3 mm.

Material examinado: BRASIL. Rio de Janeiro: Itatiaia, Trilha do Hotel Simon para os Três Picos, 1250 m, 29/ IX/2005, Sylvestre et al. 1854 (RB).

Material adicional: BRASIL. São Paulo: Sem localidade, s.d., Löfgren s.n. (RB 36983).

A espécie é endêmica do Brasil, ocorrendo nos estados de Minas Gerais, Rio de Janeiro, São Paulo, Paraná e Santa Catarina.

Huperzia loefgreniana cresce em regiões montanhosas e em matas nebulares (Øllgaard \& Windisch 1987). Na área de estudo, encontrou-se apenas um indivíduo caído de altura desconhecida, às margens da trilha para os Três Picos, em local úmido e sombreado, a $1250 \mathrm{~m}$. Espécie epífita obrigatória, $H$. loefgreniana localiza-se, principalmente, nos dosséis de matas nebulares.

1.10. Huperzia mollicoma (Spring) Holub, Folia Geobot. Phytotax. 20: 75. 1985. Lycopodium dichotomum Jacq. subsp. mollicomum Spring, Fl. 21: 162. 1838. Tipo: Brasil, Pará, Martius s.n. (holótipo M).

Fig. 20-21

Esporófitos epífitos. Caule pendente, quatro a oito vezes dicotômico, 28-41 cm compr., 5-14 mm diâm. (incluindo os microfilos) nas porções proximal e mediana, 3-16 mm diâm. (incluindo os microfilos) na porção distal, 0,5-1 mm diâm. (excluindo os microfilos) nas porções proximal e mediana, 0,3-0,5 mm diâm. (excluindo os microfilos) na porção distal, verde-oliva, com raízes adventícias emergindo num tufo basal. Microfilos expandidos sempre ausentes na porção proximal do caule. Microfilos ascendentes, irregularmente verticilados, lineares, ápice acuminado, margem inteira, venação proeminente castanho-esverdeada (quando fresco) a castanha (quando seco), membranáceos, verde-olivas, quatro a cinco microfilos por verticilo, 7-9x0,4-0,5 mm. Esporofilos distribuídos da porção mediana a distal do caule, semelhantes aos microfilos, base ligeiramente obtusa na inserção do esporângio, quatro esporofilos por verticilo, oito ou mais verticilos por porção fértil, $0,2-2,2 \mathrm{~cm}$ de porções estéreis entre as férteis, 5-7x0,5-0,6 mm. Esporângios axilares, reniformes, amarelos a amarelo-claros, 0,6-0,8x $1 \mathrm{~mm}$.

Material selecionado: BRASIL. Minas Gerais: Bocaina de Minas, Trilha para o Alto dos Brejos, $1500 \mathrm{~m}, 31 / \mathrm{V} / 2006$, $R a$ mos et al. 25 (RB). Rio de Janeiro: Itatiaia, Lote 21, 21/V/1935, Brade 14528(RB); 760 m, 12/VII/2006, Ramos et al. 39 (RB); Trilha para o Itaporani, 1/VI/2006, Ramos et al. 29 (RB); Trilha para os Três Picos, 1300 m, 30/V/2006, Ramos et al. 21 (RB).

A espécie distribui-se por toda América Tropical (Ø11gaard \& Windisch 1987). No Brasil, localiza-se nos estados do Pará, Pernambuco, Minas Gerais, Espírito Santo, Rio de Janeiro e São Paulo.

Huperzia mollicoma localiza-se em florestas, de $700 \mathrm{~m}$ a $1200 \mathrm{~m}$ (Øllgaard \& Windisch 1987). Na área de estudo, esta espécie cresce de $0,2-1 \mathrm{~m}$ do solo, no interior de mata ou às margens de trilhas. Ocorre em altitudes que variam de $760 \mathrm{~m}$ a $1500 \mathrm{~m}$.

No campo, Huperzia mollicoma pode ser confundida com $H$. acerosa e H. comans. Contudo, diferentemente de $H$. mollicoma estas espécies possuem microfilos com venação pouco proeminente e de coloração uniforme.

1.11. Huperzia nuda (Nessel) B. Øllg. \& P. G. Windisch, Bradea 5(1): 14. 1987. Urostachys nudus Christ ex Nessel, Arch. Bot. São Paulo 1: 396, t. 14. 1927. Tipo: Brasil, Campos de Itatiaia, V/1906, Luederwaldt s.n. (lectótipo SP 18082, designado por B. Øllg. \& P. G. Windisch, Bradea 5(1): 14. 1987; isolectótipo NY).

Fig. 22-23

Esporófitos terrestres ou rupícolas. Caule ascendente a ereto, às vezes decumbente, duas a três vezes dicotômico, nitidamente visível entre os verticilos de microfilos e esporofilos, $19-50 \mathrm{~cm}$ compr., 5-20 mm diâm. (incluindo os microfilos) nas porções proximal e mediana, $10-20 \mathrm{~mm}$ diâm. (incluindo os microfilos) na porção distal, 1-1,5 mm diâm. (excluindo os microfilos) nas porções proximal, mediana e distal, verde-oliva, com raízes adventícias emergindo num tufo basal, às vezes partindo perpendicularmente ao caule quando decumbente. Microfilos patentes, às vezes ascendentes, alterno-verticilados, lineares, ápice acuminado, margem inteira, venação pouco proeminente, cartáceos, verde-olivas a pardacentos, cinco microfilos por verticilo, 8-10x0,5-0,6 mm. Esporofilos distribuídos nas porções mediana e distal do caule, às vezes com porções estéreis ao final do ramo, semelhantes aos microfilos, esporângios completamente à mostra devido à orientação dos esporofilos, três a seis verticilos por porção fértil, 4-4,6 cm de porções estéreis entre as férteis, 8-10x0,5-0,6 mm. Esporângios axilares, reniformes, amarelos, $0,7-1 \times 1-1,5 \mathrm{~mm}$. 


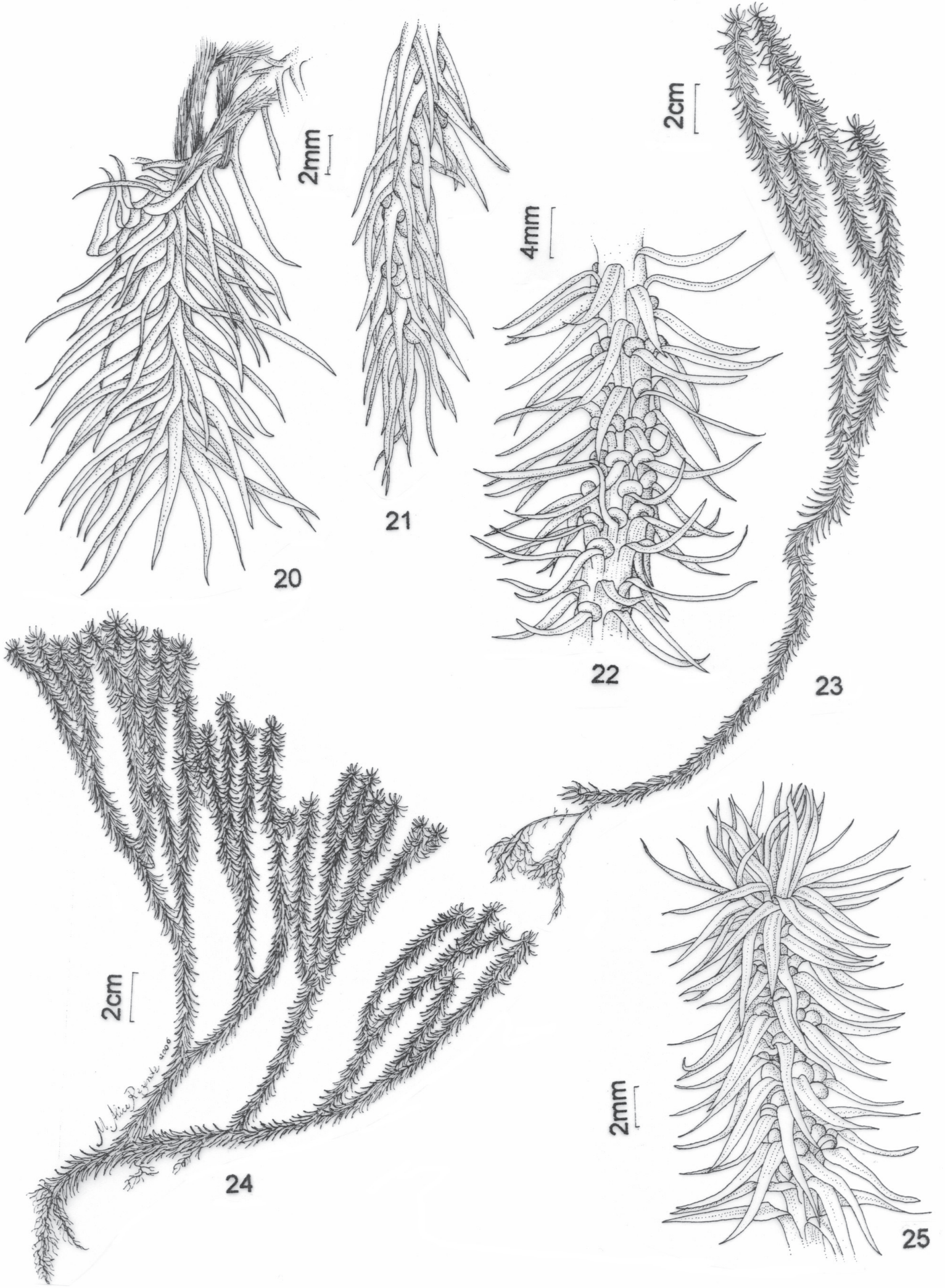

Figuras 20-21. Huperzia mollicoma (Spring) Holub. 20. Porção proximal do caule evidenciando os microfilos lineares. 21. Porção distal evidenciando os verticilos de esporofilos (Ramos et al. 21). Figuras 22-23. Huperzia nuda (Nessel) B. Øllg. \& P. G. Windisch. 22. Porção mediana, com caule visível entre os verticilos de esporofilos lineares. 23. Hábito (Ramos et al. 40). Figuras 24-25. Huperzia pungentifolia (Silveira) B. Øllg. 24. Hábito. 25. Porção distal, com caule não visível entre os verticilos de esporofilos lineares (Condack 424). 
Material selecionado: BRASIL. Rio de Janeiro: Itatiaia, Agulhas Negras, $2650 \mathrm{~m}, 8 / \mathrm{VIII} / 2006$, Condack \& Ramos 522 (RB); Estrada para o Planalto, 13/VII/2006, Ramos et al. 40 (RB); Estrada para o Véu da Noiva, 1100 m, 1/VI/2006, Ramos et al. 32 (RB); Mata de frente para o Abrigo Massena, 18/VIII/2004, Sylvestre \& Condack 1767 (RB); Trilha para a Cachoeira Poranga, 6/XI/1995, Braga et al. 2957 (RB).

A espécie é endêmica do Brasil, ocorrendo nos estados do Rio de Janeiro e São Paulo.

Huperzia nuda é restrita a matas nebulares de regiões mais elevadas no sudeste brasileiro, ocorrendo entre 10002100 m (Øllgaard \& Windisch 1987). Øllgaard (1992) acredita que esta espécie possa ser derivada de espécies andinas. No PNI, os espécimes crescem sobre rochas ou em barrancos, às margens de trilhas ou rios, heliófilos, em altitudes que variam de 1000-2650 m.

Como em Huperzia badiniana, alguns indivíduos de $H$. nuda apresentam caule decumbente. No entanto, H. badiniana possui caule não visível entre os verticilos e microfilos e esporofilos lanceolados, com margem sinuosa.

1.12. Huperzia pungentifolia (Silveira) B. Øllg., Opera Bot. 92: 169. 1987. Lycopodium pungentifolium Silveira, Bol. Comm. Geogr. Geol. Minas Geraes 2, 5: 119, t. 4. 1898. Tipo: Brasil, Minas Gerais, Magalhães s.n., In Herb. Comm. Geog. et Geolog. civ. Minas Geraes (holótipo P). Fig. 24-25

Esporófitos terrestres. Caule ascendente a ereto, às vezes decumbente, quatro a seis vezes dicotômico, não visível entre os verticilos de microfilos e esporofilos, 13,5-27 cm compr., 7-20 mm diâm. (incluindo os microfilos) nas porções proximal e mediana, 7-15 mm diâm. (incluindo os microfilos) na porção distal, 2-3 mm diâm. (excluindo os microfilos) na porção proximal, diminuindo para 1,5-2 $\mathrm{mm}$ na porção distal, verde-oliva, com raízes adventícias emergindo num tufo basal, às vezes partindo perpendicularmente ao caule quando decumbente. Microfilos patentes, às vezes ascendentes, irregularmente verticilados, lineares, ápice acuminado, margem inteira, venação pouco proeminente, coriáceos, verde-olivas, cinco a seis microfilos por verticilo, $8-10 \times 0,5-1 \mathrm{~mm}$. Esporofilos localizados na porção distal do caule, às vezes com porções estéreis ao final do ramo, semelhantes aos microfilos, cinco a dez verticilos por porção fértil, 7-8x0,7-1 mm. Esporângios axilares, reniformes, amarelos, $0,5-1,1 \times 1,5-3,1 \mathrm{~mm}$.

Material examinado: BRASIL. Rio de Janeiro: Itatiaia, Caminho para Pedra Assentada, proximidades da Pedra da Maçã, 2400 m, 20/VIII/2005, Condack 424 (RB).

Material adicional: BRASIL. Minas Gerais: Santo Antônio do Itambé, estrada para o Pico do Itambé, 16/VII/1987, Prado et al. s.n. (RB 323529). Rio de Janeiro: Petrópolis, Vale das Videiras, Morro do Cuca, 1500-1750 m, 10/X/1979, Martinelli \& Santos 6150 (RB).
A espécie é endêmica do Brasil, ocorrendo nos estados de Minas Gerais e Rio de Janeiro.

Huperzia pungentifolia é observada em fendas de rochas nas montanhas, entre $1200 \mathrm{~m}$ a $1800 \mathrm{~m}$ (Øllgaard \& Windisch 1987). No PNI, o único indivíduo localizado cresce às margens da trilha, em ambiente úmido, a 2400 $\mathrm{m}$, apresentando caule decumbente, caráter não observado nos materiais examinados adicionalmente. Neste único indivíduo, as porções férteis situavam-se na mesma altura nos diferentes ramos.

Huperzia pungentifolia pode ser inicialmente confundida com H. nuda. Contudo, esta apresenta caule menos ramificado e visível entre os verticilos de microfilos e esporofilos.

1.13. Huperzia quadrifariata (Bory) Rothm., Feddes Repert. 54: 60. 1944. Lycopodium quadrifariatum Bory, In Duperrey, Voy. monde Bot. 1: 245. 1829. Tipo: Brésil, île de Ste. Catherine, d'Urville s.n. (holótipo P).

Fig. 26-27

Esporófitos epífitos ou terrestres. Caule pendente, quadrangular (incluindo os microfilos) em toda sua extensão, três a seis vezes dicotômico, $36-60$ cm compr., 2-4 mm diâm. (incluindo os microfilos) nas porções proximal e mediana, 1,5$2 \mathrm{~mm}$ diâm. (incluindo os microfilos) na porção distal, 1,3-2 $\mathrm{mm}$ diâm. (excluindo os microfilos) nas porções proximal e mediana, 1-1,3 mm diâm. (excluindo os microfilos) na porção distal, verde-oliva, com raízes adventícias emergindo num tufo basal. Microfilos expandidos presentes ou não na porção proximal do caule, patentes, alterno-verticilados, linear-oblongos, ápice obtuso, margem inteira, venação pouco proeminente, cartáceos, verde-olivas a castanhos, três a quatro microfilos por verticilo, 4-12x1-3 mm. Microfilos adpressos localizados em toda a extensão do caule, opostos ou alterno-verticilados, imbricados, triangular-ovados, presença de carena, ápice agudo e conduplicado, levemente esbranquiçado, margem inteira e levemente esbranquiçada, venação pouco proeminente, coriáceos, verde-olivas, três microfilos por verticilo (proximal) a dois microfilos opostos (mediana e distal), 2-4x1-3 mm. Esporofilos localizados na porção distal do caule, às vezes com porções estéreis ao final do ramo, semelhantes aos microfilos adpressos, dois esporofilos ascendentes, opostos, imbricados, seis ou mais pares de esporofilos opostos por porção fértil, 0,5-1,2 cm de porções estéreis entre as férteis, 1-2x1-1,4(-2) $\mathrm{mm}$. Esporângios axilares, subglobosos, amarelos a amareloclaros, $0,8-1,2 \times 0,9-1,4 \mathrm{~mm}$.

Material examinado: BRASIL. Rio de Janeiro: Itatiaia, Estrada para o Véu da Noiva, 1100 m, 1/VI/2006, Ramos et al. 30 (RB); Lote 21, 760 m, 12/VII/2006, Ramos et al. 37 (RB); Trilha para os Três Picos, 1250 m, 30/V/2006, Ramos et al. 19 (RB).

Espécie endêmica do Brasil, ocorrendo nos estados de Roraima, Minas Gerais, Espírito Santo, Rio de Janeiro, São Paulo, Paraná e Santa Catarina.

Huperzia quadrifariata ocorre em florestas montanas úmidas de 100-1300 m (Øllgaard \& Windisch 1987). Espécie 


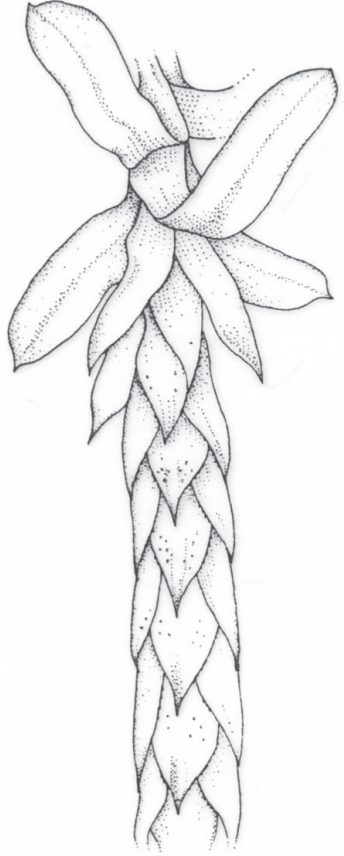

26

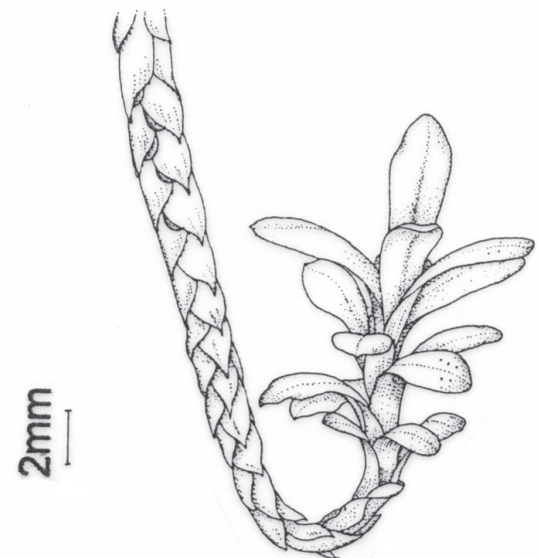

27
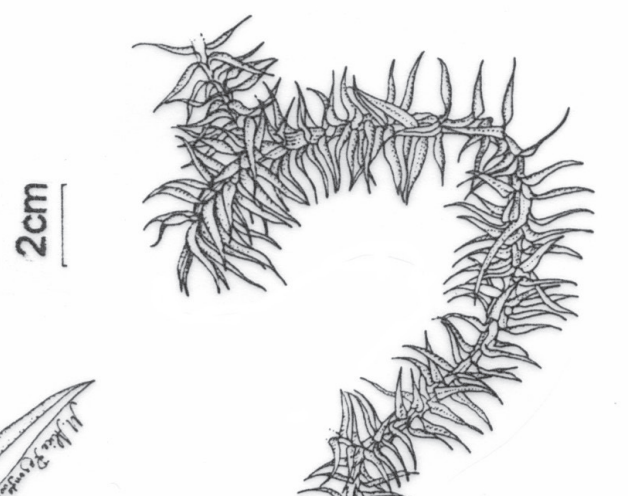
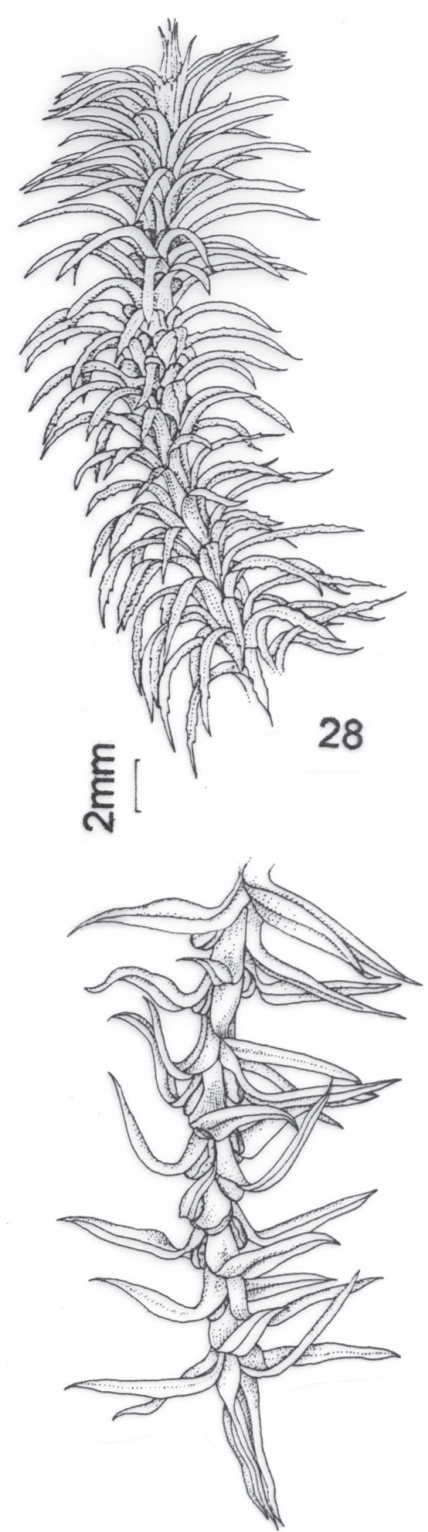

31

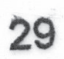

Figuras 26-27. Huperzia quadrifariata (Bory) Rothm. 26. Porção proximal do caule mostrando os microfilos adpressos e os microfilos expandidos. 27. Porção distal do caule mostrando os esporofilos, seguidos de um ramo propagado, apresentando os microfilos expandidos típicos da porção proximal do caule (Ramos et al. 19). Figura 28. Huperzia reflexa (Lam.) Trevis. - Porção distal do caule com microfilos e esporofilos reflexos, de margem denticulada (Ramos et al. 15). Figuras 29-31. Huperzia silveirae (Nessel) B. Øllg. \& P. G. Windisch. 29. Porção mediana do caule com microfilos lanceolados. 30. Hábito. 31. Porção distal do ramo fértil (Ramos et al. 24). 
epífita preferencial, crescendo ca. $3 \mathrm{~m}$ do solo. Encontra-se, na área de estudo, em ambientes sombreados, no interior da mata ou às margens da estrada, em altitudes que variam de 760-1250 m.

Semelhante a Huperzia hexasticha, os microfilos expandidos de Huperzia quadrifariata nem sempre são observados, pois se fragmentam facilmente ao longo do tempo, principalmente em ambientes secos. Todavia, $H$. hexasticha possui caule arredondado-angular (incluindo os microfilos) na porção proximal a agudo-quadrangular (incluindo os microfilos) nas porções mediana e distal, microfilos expandidos oblongos e microfilos adpressos e esporofilos de ápice não conduplicado.

Alguns representantes terrestres da espécie detêm, na porção distal do caule, ramos propagados com microfilos típicos da porção proximal do caule.

1.14. Huperzia reflexa (Lam.) Trevis., Atti Soc. Ital. Sci. Nat. 17: 248. 1874. Lycopodium reflexum Lam., Encycl. 3: 653. 1789 [1792]. Tipo: Martinique, Comm. Joseph Martin s.n. (holótipo P-Lam. 442).

Fig. 28

Esporófitos terrestres ou rupícolas. Caule ascendente a ereto, duas a cinco vezes dicotômico, $18-35$ cm compr., 7-20 $\mathrm{mm}$ diâm. (incluindo os microfilos) nas porções proximal, mediana e distal, 1,5-2 mm diâm. (excluindo os microfilos) na porção proximal, diminuindo para $0,5-1,0 \mathrm{~mm}$ na porção distal, verde, com raízes adventícias emergindo num tufo basal. Microfilos reflexos, raro ascendentes, alternoverticilados, linear-subulados, ápice acuminado, margem denticulada, venação pouco proeminente, herbáceos a cartáceos, verde-olivas, seis a oito microfilos por verticilo, 3,5-11x0,5-1,5 mm. Esporofilos distribuídos da porção proximal a distal do caule, semelhantes aos microfilos, sete ou mais verticilos por porção fértil, 3,5-7x0,5-0,7 mm. Esporângios axilares, reniformes, amarelos a verde-claros, 0,5-1x1,3-1,7 mm.

Material selecionado: BRASIL. Rio de Janeiro: Itatiaia, Abrigo Rebouças, 2300 m, 11/X/1977, Maas \& Martinelli 3187 (RB); Caminho Rebouças-Prateleiras, 5/V/2005, Ramos et al. 13 (RB); Lote 17, 24/V/1932, Campos Porto 2595 (RB); Trilha do Hotel Simon para o Maromba, $850 \mathrm{~m}$, 5/V/2005, Ramos et al. 15 (RB).

A espécie distribui-se por toda América Tropical (Øllgaard \& Windisch 1987). No Brasil, encontra-se nos estados do Mato Grosso do Sul, Minas Gerais, Rio de Janeiro, São Paulo, Paraná, Santa Catarina e Rio Grande do Sul.

Os representantes desta espécie são observados, geralmente, em florestas montanas entre $350 \mathrm{~m}$ a $2000 \mathrm{~m}$ (Ø11gaard \& Windisch 1987). Na área de estudo, ocorrem em ambiente úmido, às margens da estrada, em altitudes entre $800 \mathrm{~m}$ e $2300 \mathrm{~m}$.

Huperzia reflexa é reconhecida, principalmente, pelos microfilos e esporofilos reflexos, com margem denticula- da. No campo, pode ser confundida com $H$. friburguensis (Nessel) B. Øllg. \& P. G. Windisch, espécie endêmica do Sudeste do Brasil (Øllgaard \& Windisch 1987), a qual não foi registrada para a área de estudo. Todavia, esta espécie apresenta caule de comprimento maior e menos ramificado (Øllgaard 1992).

1.15. Huperzia silveirae (Nessel) B. Øllg. \& P. G. Windisch, Bradea 5(1): 17. 1987. Urostachys silveirae Herter ex Nessel, Arch. Bot. São Paulo 1: 386. 1927. Tipo: Brasil, Minas Gerais, Serra do Bispo, Silveira s.n. (holótipo BONN-herb. Nessel 144).

Fig. 29-31

Esporófitos epífitos, raro terrestres. Caule pendente, uma a duas vezes dicotômico, 8,5-39,5 cm compr., 20-30 $\mathrm{mm}$ diâm. (incluindo os microfilos) nas porções proximal e mediana, $15-28 \mathrm{~mm}$ diâm. (incluindo os microfilos) na porção distal, 1-2 mm diâm. (excluindo os microfilos) nas porções proximal e mediana, 0,5-1 mm diâm. (excluindo os microfilos) na porção distal, verde-amarelado a castanho, com raízes adventícias emergindo num tufo basal. Microfilos expandidos sempre ausentes na porção proximal do caule. Microfilos ascendentes a patentes, alterno-verticilados, lanceolados, ápice acuminado não conduplicado, margem inteira, com coloração uniforme, venação proeminente, herbáceos, verde-olivas, três microfilos por verticilo, 8-20x1-2 $\mathrm{mm}$. Esporofilos distribuídos nas porções mediana e distal do caule, às vezes com porções estéreis ao final do ramo, semelhantes aos microfilos, base ligeiramente arredondada na inserção do esporângio, dois a cinco verticilos por porção fértil, 1,5-3,3 cm de porções estéreis entre as férteis, 7-15x1-1,8 mm. Esporângios axilares, reniformes, amarelos, $1,2-1,3 \times 1,5-1,7 \mathrm{~mm}$.

Material selecionado: BRASIL. Minas Gerais: Bocaina de Minas, Alto dos Brejos, 2000 m, 27/X/2006, Ramos et al. 73 (RB). Rio de Janeiro: Itatiaia, Rio Bonito, Cachoeira Bela Vista, 30/V/2006, Ramos et al. 24 (RB).

A espécie é endêmica do Brasil, ocorrendo nos estados de Minas Gerais, Rio de Janeiro, São Paulo, Paraná e Santa Catarina.

Huperzia silveirae é encontrada em florestas montanas elevadas, entre $800 \mathrm{~m}$ e $2000 \mathrm{~m}$ (Øllgaard \& Windisch 1987). No PNI, esta espécie cresce a 0,5-2 $\mathrm{m}$ do solo, no interior de mata, nas margens de trilhas ou próxima a cursos d'água, em locais sombreados. Pode ser observada em altitudes que variam entre $1560 \mathrm{~m}$ e $2000 \mathrm{~m}$.

Huperzia heterocarpon é afim, mas difere de H. silveirae pelos microfilos e esporofilos linear-lanceolados, com ápice longo-acuminado e largura menor.

\section{Lycopodiella Holub, Preslia 36: 20, 22. 1964. Tipo: Lyco-} podiella inundata (L.) Holub, Preslia 36(1): 21. 1964.

Esporófitos terrestres, raro rupícolas. Caule primário reptante a sarmentoso, com ramo secundário inserido dorsalmente, glabro, ramificado anisotomicamente, heteroblástico. 
Raízes adventícias perpendiculares à face inferior do caule primário. Ramo secundário ereto ou prostrado, simples ou ramificado, não estolonífero, com microfilos homófilos e isófilos. Estróbilos sempre sésseis, terminais, cônicos, eretos ou pendentes. Esporofilos sempre modificados, efêmeros após a dispersão dos esporos, reunidos em estróbilos. Esporângios axilares ou basais, subglobosos a reniformes, anisovalvados. Gametófito superficial, hemi-micoparasítico.

Lycopodiella tem ampla distribuição geográfica, possuindo 25 espécies neotropicais (Øllgaard 1992, 1995), com 11 espécies e cinco variedades citadas para o Brasil. Observou-se, para o PNI, quatro espécies e uma variedade preferencialmente terrestres, correspondentes a $36 \%$ das Lycopodiella citadas para o país, e $80 \%$ das espécies ocorrentes para o Rio de Janeiro.

Chave para identificação das espécies e variedades de Lycopodiella no Parque Nacional do Itatiaia

1. Ramo secundário simples

2.1. L. alopecuroides var. duseniana

1. Ramo secundário ramificado

2. Estróbilos pendentes 2.3.L.cernua

2. Estróbilos eretos

3. Ramo secundário prostrado; esporofilos ovados, margem inteira 2.2. L. bradei

3. Ramo secundário ereto; esporofilos linear-lanceolados, margem denticulada..... 2.4. L. geometra

\subsection{Lycopodiella alopecuroides (L.) Cranfill var. duseniana}

B. Øllg. \& P. G. Windisch, Bradea 5: 29, f. 4D. 1987.

Tipo: Brasil, Estado do Rio de Janeiro, Itatiaia, Retiro, 19/V/1902, Dusén 165 (holótipo S; isótipo R!).

Fig. 32

Esporófitos terrestres. Caule primário longo-reptante, 10-13 mm diâm. (incluindo os microfilos), 0,8-2 mm diâm. (excluindo os microfilos), verde-oliva; microfilos ascendentes a patentes, alterno-verticilados, lineares a linear-lanceolados, ápice acuminado, margem inteira, papiráceos, verde-olivas, seis a sete microfilos por verticilo, 3-11 x0,5-1 mm. Ramo secundário ereto, simples, 6,5-14,3 cm compr., 8-13 mm diâm. (incluindo os microfilos), 2-2,5 mm diâm. (excluindo os microfilos), verde-oliva, glabro; microfilos ascendentes, alterno-verticilados, linear-lanceolados, ápice acuminado, margem inteira, venação proeminente, papiráceos, verde-olivas a pardacentos, quatro a oito microfilos por verticilo, 9-11x1 mm. Estróbilo séssil, ereto, no ápice do ramo secundário, 4,8-11,5x1,5-2 cm. Esporofilos ascendentes a patentes, alterno-verticilados, linear-lanceolados, ápice longo-acuminado e inteiro, margem esparsamente denticulada, base obtusa na inserção do esporângio, venação proeminente, membranáceos, pardacentos, dez ou mais esporofilos por verticilo, 9-12,5x1-2 $\mathrm{mm}$. Esporângios axilares, subglobosos a reniformes, castanhos, 0,5-0,7x1,2-1,5 mm.
Material selecionado: BRASIL. Rio de Janeiro: Itatiaia, Caminho Rebouças-Agulhas Negras, 2400 m, 8/ VIII/2006, Ramos et al. 53 (RB); Lagoa das Prateleiras, 2300 m, III/1937, Brade 15567 (RB); Proximidades do Abrigo Massena, 2100 m, 26/V/2005, Condack \& Cortines 380 (RB); Trilha para o Pico das Agulhas Negras, 2500 m, 25/IX/1995, Braga et al. 2855 (RB).

Lycopodiella alopecuroides var. duseniana cresce em altitudes elevadas (Øllgaard \& Windisch 1987). No PNI, foi observada em locais brejosos, em altitudes que variam de $1500 \mathrm{~m}$ a $2500 \mathrm{~m}$.

No campo, a variedade é facilmente reconhecida pelo caule primário verde-oliva ramificado, do qual parte um ramo secundário pardacento, simples, portando um estróbilo largo.

2.2. Lycopodiella bradei (Herter) B. Øllg., Opera Bot. 92: 176. 1987. Lycopodium bradei Herter, Revista Sudamer. Bot. 8: 21. 1949. Tipo: Brasil, Serra do Caparaó, Lajão, 18/IX/1941, Brade 16959 (holótipo RB!; isótipo AAU). Fig. 33-34

Esporófitos rupícolas. Caule primário reptante, 3,5-6 $\mathrm{mm}$ diâm. (incluindo os microfilos), 0,8-1,8 mm diâm. (excluindo os microfilos), castanho (material seco); microfilos ascendentes a patentes, irregularmente verticilados, lineares a linear-lanceolados, ápice acuminado, margem inteira, subcoriáceos, castanhos (material seco), quatro a seis microfilos por verticilo, 2,5-4,5x0,2-0,4 mm. Ramo secundário prostrado, várias vezes ramificado, 3-4,5 $\mathrm{cm}$ compr., 2,5-4,5 mm diâm. (incluindo os microfilos), 0,5-1 mm diâm. (excluindo os microfilos), castanho (material seco), glabro; microfilos ascendentes, irregularmente verticilados, linear-lanceolados, ápice acuminado, margem inteira, venação pouco proeminente, subcoriáceos, castanhos (material seco), quatro a cinco microfilos por verticilo, 2,5-5x0,1-0,4 mm. Estróbilos sésseis, eretos, no ápice de ramificações laterais, 5-7,5x2,5-3,5 mm. Esporofilos ascendentes, irregularmente verticilados, ovados, ápice longo-acuminado, margem inteira, base arredondada a obtusa na inserção do esporângio, venação não proeminente, subcoriáceos, castanhos (material seco), quatro a cinco esporofilos por verticilo, 1,2-2x0,3-0,6 mm. Esporângios axilares, subglobosos a globosos, amarelos, inclusos em uma cavidade na parede do estróbilo, 0,6x0,6-0,9 mm.

Material examinado: BRASIL. Rio de Janeiro: Itatiaia, Agulhas Negras, 20/X/1922, Campos Porto 1121 (RB).

Material adicional: BRASIL. Santa Catarina: Mafra, 750 m, 26/I/1953, Reitz 5319 (PACA).

A espécie é endêmica do Brasil, ocorrendo nos estados de Minas Gerais (Pico da Bandeira), Rio de Janeiro (Agulhas Negras) e Santa Catarina.

Lycopodiella bradei é considerada rara, com ausência de registros recentes para a área de estudo, pois o único e último registro de coleta data de 1922. Encontrada em altitudes que variam entre $2300 \mathrm{~m}$ e $2500 \mathrm{~m}$ (Øllgaard \& Windisch 1987). 

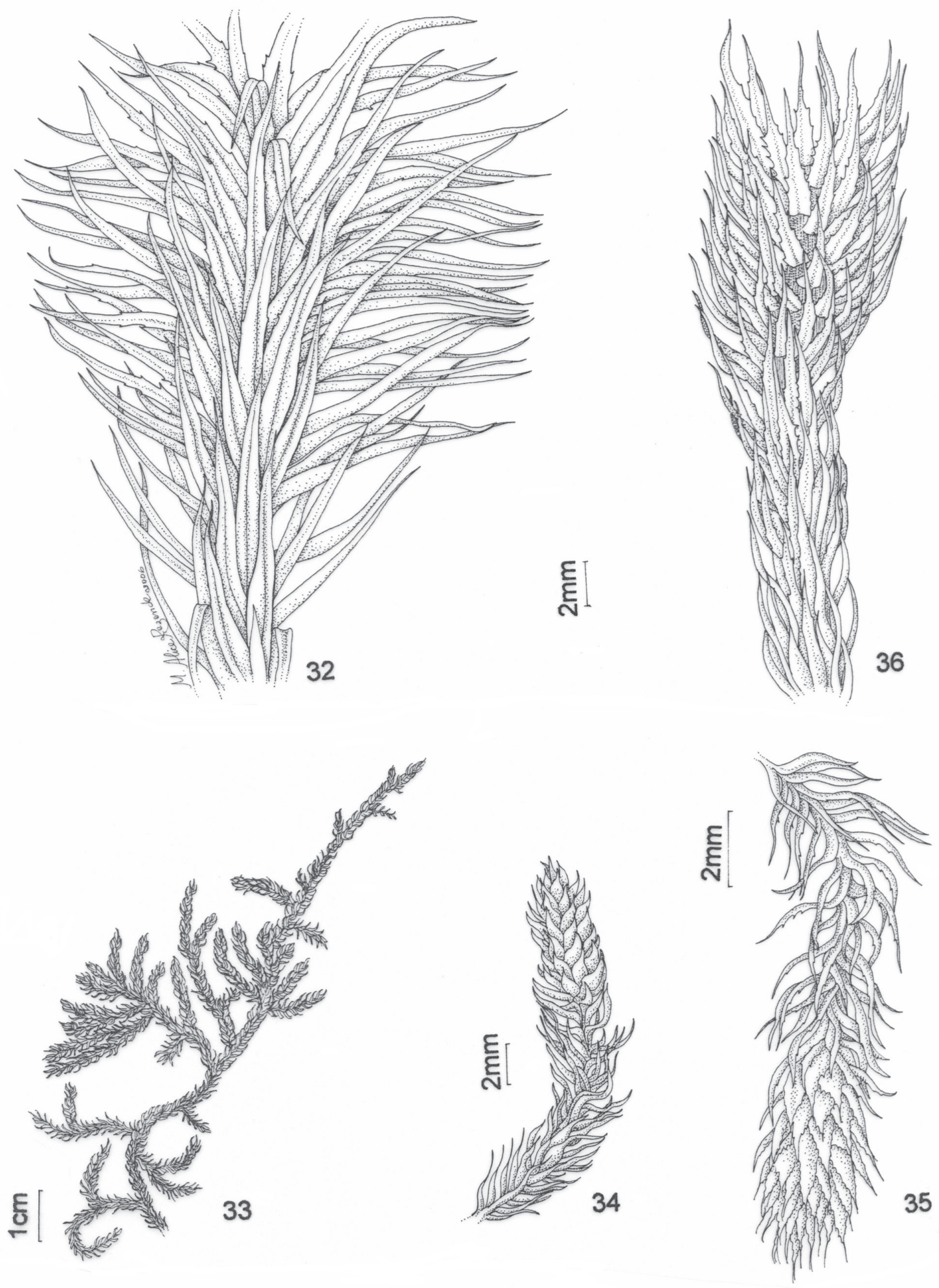

Figura 32. Lycopodiella alopecuroides var. duseniana B. Øllg. \& P. G. Windisch - Ramo secundário evidenciando microfilos com margem inteira e esporofilos com margem esparsamente denticulada (Ramos et al. 53). Figura 33-34. Lycopodiella bradei (Herter) B. Øllg. 33. Hábito. 34. Estróbilo ereto, evidenciando esporofilos ovados, com margem inteira (Campos Porto 1121). Figura 35. Lycopodiella cernua (L.) Pic. Serm. - Estróbilo pendente, evidenciando esporofilos com margem lacerada (Ramos \& Sylvestre 17). Figura 36. Lycopodiella geometra B. Øllg. \& P. G. Windisch - Ramo secundário evidenciando os microfilos e os esporofilos (Condack \& Ramos 458). 
A espécie é caracterizada, principalmente, pelo ramo secundário prostrado, estróbilos eretos e esporângios inclusos em uma cavidade na parede do estróbilo.

2.3. Lycopodiella cernua (L.) Pic. Serm., Webbia 23: 165. 1968. Lycopodium cernuum L., Sp. Pl. 1103. 1753. Tipo: "Habitat in Indiis", In Herb. Linn. 1257.13 (lectótipo LINN, designado por Proctor, Ferns of Jamaica 26. 1985).

Fig. 35

Esporófitos terrestres, raro rupícolas. Caule primário sarmentoso, 3-5 mm diâm. (incluindo os microfilos), 1-1,5 mm diâm. (excluindo os microfilos), amareloesverdeado; microfilos ascendentes a patentes, alternoverticilados, aciculares, margem inteira, papiráceos, verdes, três a seis microfilos por verticilo, $3-5 \times 0,2-0,3$ $\mathrm{mm}$. Ramo secundário ereto, várias vezes ramificado, ca. $18 \mathrm{~cm}$ compr., 5-7 mm diâm. (incluindo os microfilos), 1-1,5 mm diâm. (excluindo os microfilos), verde, presença de tricomas simples na base dos microfilos; microfilos patentes, alterno-verticilados, aciculares, margem inteira, venação pouco proeminente, membranáceos, verdes, quatro a cinco microfilos por verticilo, 2,5-4x0,3-0,5 $\mathrm{mm}$. Estróbilos sésseis, pendentes, no ápice de ramificações laterais, 4-9x2-3 mm. Esporofilos ascendentes, alterno-verticilados, deltóides a ovados, ápice caudado, margem lacerada, base obtusa na inserção do esporângio, venação não proeminente, membranáceos, amarelos, quatro a cinco esporofilos por verticilo, 1,8-2,5x0,7-1,0 $\mathrm{mm}$. Esporângios basais, subglobosos, amarelos, 0,4$0,5 \times 0,5-0,6 \mathrm{~mm}$.

Material selecionado: BRASIL. Rio de Janeiro: Itatiaia, Caminho Prateleiras-Rebouças, 10/VIII/2006, Ramos et al. 69 (RB); Estrada que liga o Maromba à Sede, 27/III/2006, Ramos \& Sylvestre 17 (RB); Serra da Capelinha, VII/1937, Lanstyak 79 (RB).

Lycopodiella cernua possui distribuição Pantropical (Øllgaard \& Windisch 1987).

A espécie é considerada pioneira (Øllgaard \& Windisch 1987). Encontra-se, no PNI, formando densas populações, muitas vezes escandentes em barrancos úmidos e ensolarados, às margens da estrada, em altitudes que variam entre 800-2400 m, podendo ocorrer desde o nível do mar (Øllgaard $\&$ Windisch 1987).

É considerada uma espécie invasora, crescendo no Parque apenas nos locais mais visitados e impactados, como observado por Condack (dados não publicados).

Lycopodiella cernua é uma espécie de fácil reconhecimento no campo, devido ao aspecto do ramo secundário em forma de "pinheiro" (deltóide).

2.4. Lycopodiella geometra B. Øllg. \& P. G. Windisch, Bradea 5: 30, f. 4A. 1987. Tipo: Brasil, Estado de Minas Gerais, Município de Santana do Riacho, estrada de La- goa Santa a Conceição do Mato Dentro, km 132 (antigo), Serra do Cipó, campo rupestre, entre gramíneas, alt. ca. 1250 m, II/1987, Prado et al. 80 (holótipo HB!; isótipos AAU, SP!, SPF).

Fig. 36

Esporófitos terrestres. Caule primário sarmentoso, 8-11 mm diâm. (incluindo os microfilos), 2-10 mm diâm. (excluindo os microfilos), verde-oliva; microfilos ascendentes, alterno-verticilados, linear-subulados, ápice acuminado, margem inteira a pouco denticulada, membranáceos, verde-olivas, cinco a sete microfilos por verticilo, 5-7x0,6-0,7 mm. Ramo secundário ereto, 2-3 ramificado, ca. $30 \mathrm{~cm}$ compr., 4-5,5 mm diâm. (incluindo os microfilos), 1,5-2 mm diâm. (excluindo os microfilos), amarelo, glabro; microfilos ascendentes a adpressos, irregularmente verticilados, linear-subulados, ápice longo-acuminado e inteiro, margem esparsa a levemente denticulada, venação proeminente, cartáceos, amarelos, oito a nove microfilos por verticilo, 4,5-6x0,5-0,6 mm. Estróbilos sésseis, eretos, no ápice do ramo secundário, 18-45x7-8 mm. Esporofilos ascendentes a adpressos, irregularmente verticilados, linear-lanceolados, ápice longo-acuminado e inteiro, margem denticulada, base arredondada na inserção do esporângio, venação proeminente, membranáceos, amarelos, oito a nove esporofilos por verticilo, 5-6,5x0,5-0,8 mm. Esporângios axilares, globosos, amarelos, 0,8-1 x0,8-1 mm.

Material examinado: BRASIL. Minas Gerais: Bocaina de Minas, Alto dos Brejos, 1900 m, 31/V/2006, Condack \& Ramos 458 (RB).

Material adicional: BRASIL. Minas Gerais: Carandaí, 25/XI/1946, Duarte 623 (RB). Paraná: Serra da Esperança, 1100 m, 17/II/1949, Brade 19723 (RB).

A espécie distribui-se do Paraguai ao norte da Argentina, e Brasil, nos estados de Minas Gerais, Rio de Janeiro, São Paulo, Paraná, Santa Catarina e Rio Grande do Sul.

Lycopodiella geometra é encontrada em vegetação campestre, em locais abertos, úmidos ou encharcados, entre 700-1300 m (Øllgaard \& Windisch 1987). No PNI, o único espécime observado cresce em um pequeno brejo, podendo o caule primário encontrar-se submerso ou não no espelho d'água. Localiza-se em ambiente aberto e ensolarado, a $1900 \mathrm{~m}$, junto a uma população de $H u$ perzia christii.

Essa espécie pode ser confundida com Lycopodiella alopecuroides var. integerrima (Spring) B. Øllg. \& P. G. Windisch, variedade não encontrada na área de estudo. Enquanto L. alopecuroides var. integerrima apresenta caule primário reptante e ramo secundário simples, L. geometra apresenta caule primário sarmentoso e ramo secundário duas a três vezes ramificado.

3. Lycopodium L., Sp. Pl. 2. 1100-1106. 1753. Lectótipo: Lycopodium clavatum L. (designado por Jonsell \& Jarvis, Reg. Veg. 127: 63. 1993). 
Esporófitos terrestres ou rupícolas. Caule primário rizomatoso a longo-reptante, com ramo secundário inserido lateralmente, glabro, ramificado anisotomicamente, heteroblásticos. Raízes adventícias perpendiculares à face inferior do caule primário. Ramo secundário ereto, várias vezes ramificado, não estolonífero e glabro, com microfilos homófilos ou heterófilos, isófilos ou anisófilos. Estróbilos sésseis ou pedunculados, pedúnculos simples ou furcados, terminais, cônicos, sempre eretos. Esporofilos sempre modificados, venação não proeminente, efêmeros após a dispersão dos esporos, reunidos em estróbilos. Esporângios basais, reniformes, isovalvados. Gametófito subterrâneo, micoparasítico.

Lycopodium possui oito espécies para a região Neotropical (Øllgaard 1992; 1993; 1995). Destas, cinco são citadas para o Brasil (Øllgaard 1992; 1993; 1995; Øllgaard \& Windisch 1987). Observaram-se, para o PNI, quatro espécies preferencialmente terrestres, correspondentes a $80 \%$ dos Lycopodium citados para o país, e $100 \%$ das espécies ocorrentes para o Rio de Janeiro.

Chave para identificação das espécies de

Lycopodium no Parque Nacional do Itatiaia

1. Ramo secundário com filotaxia radial

2. Microfilos com ápice rígido; esporofilos com ápice longo-acuminado, margem ondulada

3.1. L. assurgens

2. Microfilos com ápice membranáceo ou filiforme; esporofilos com ápice acuminado, margem denticulada.

3.2. L. clavatum

1. Ramo secundário com filotaxia dorsiventral

3. Microfilos dispostos em duas fileiras laterais e duas ventrais; esporofilos ovados, ápice acuminado, margem eroso-denticulada

3.3. L. jussiaei

3. Microfilos dispostos em duas fileiras laterais, uma dorsal e uma ventral; esporofilos deltóides, ápice longo-cuspidado, margem inteira a crenulada. 3.4.L.thyoides

3.1. Lycopodium assurgens Fée, Cryptog. Vasc. Brésil 2: 95, t. 106, f. 3. 1872-73. Tipo: Brasil, Itatiaia, Glaziou 5228 (holótipo P; isótipos C, K, S).

Fig. 37

Esporófitos terrestres. Caule primário rizomatoso, ca. $3 \mathrm{~mm}$ diâm. (incluindo os microfilos), 2,5-3 mm diâm. (excluindo os microfilos), verde-oliva; microfilos raros, adpressos, alterno-verticilados, espatulados, ápice redondo, margem inteira no meio e na base, erosa no ápice, membranáceos, dois a três microfilos por verticilo, 2,4-3,5x1-1,5 $\mathrm{mm}$. Ramo secundário ereto, 14,9-24,7 cm compr., 3-5 mm diâm. (incluindo os microfilos), 0,5-1,5 mm diâm. (excluindo os microfilos), verde, filotaxia radial; microfilos ascendentes, alterno-verticilados, aciculares, ápice rígido, margem inteira, papiráceos, três a quatro microfilos por verticilo, 3,3-7x0,4-0,5 mm. Estróbilos sésseis ou pedunculados; pedúnculos simples ou furcados, 1-2,5 cm compr.; um a três estróbilos por pedúnculo, 10-20x4-5 mm. Esporofilos alterno-verticilados, ovados, ápice longo-acuminado, margem ondulada, base arredondada a obtusa na inserção do esporângio, membranáceos, três a quatro esporofilos por verticilo, 1,6-4,2x0,5-1 mm. Esporângios basais, reniformes, amarelos, 0,5-1,2x1 mm.

Material selecionado: BRASIL. Rio de Janeiro: Itatiaia, Caminho Agulhas Negras-Rebouças, 8/VIII/2006, Ramos et al. 61 (RB); Caminho para a Pedra do Altar, ca. de 2660, 9/ VIII/2006, Ramos et al. 64 (RB); Estrada para o Planalto, 13/VII/2006, Ramos et al. 46 (RB); Lagoa Seca, 2200 m, VIII/1933, Brade 12629 (RB).

A espécie distribui-se no Chile, Argentina e Brasil, nos estados de Minas Gerais, Rio de Janeiro, Santa Catarina e Rio Grande do Sul.

Lycopodium assurgens ocorre em campos de altitude entre 1900 m e 2750 m, nos estados de Minas Gerais e Rio de Janeiro, e entre $900 \mathrm{~m}$ e $1000 \mathrm{~m}$ de altitude nos estados de Santa Catarina e Rio Grande do Sul (Øllgaard \& Windisch 1987). No PNI, cresce sobre barrancos ou em locais rochosos, em ambientes úmidos e ensolarados, entre altitudes que variam de $2100 \mathrm{~m}$ a $2660 \mathrm{~m}$.

Espécimes de Lycopodium clavatum que possuem microfilos com ápice membranáceo podem ser confundidos com Lycopodium assurgens. Lycopodium clavatum diferencia-se por apresentar caule primário longo-reptante, microfilos com ápice membranáceo ou filiforme, esporofilos com ápice acuminado e margem denticulada.

3.2. Lycopodium clavatum L., Sp. Pl. 1101. 1753. Tipo: "Habitat in Europae sylvis muscosis" (holótipo LINN 1257.2).

Fig. 38-39

Esporófitos terrestres. Caule primário longo-reptante, 3-12 mm diâm. (incluindo os microfilos), 1,5-2,5 mm diâm. (excluindo os microfilos), verde-oliva a pardacento; microfilos ascendentes, alterno-verticilados, lineares a aciculares, ápice membranáceo ou filiforme, margem inteira, papiráceos, quatro a sete microfilos por verticilo, 6-8x0,4-0,5 mm. Ramo secundário ereto, 15-42 cm compr., 4-14 mm diâm. (incluindo os microfilos), 0,5-1,5 mm diâm. (excluindo os microfilos), verde-oliva, filotaxia radial; microfilos ascendentes, alterno-verticilados, lineares a aciculares, ápice membranáceo ou filiforme, margem inteira, papiráceos a cartáceos, quatro a dez microfilos por verticilo, 4-10x0,4$0,6 \mathrm{~mm}$. Estróbilos sésseis ou pedunculados; pedúnculos furcados, 3-8,5 cm compr.; dois a quatro estróbilos por pedúnculo, 10-30x3-7 mm. Esporofilos alterno-verticilados, triangulares a ovados, ápice acuminado, margem denticulada, base arredondada a obtusa na inserção do esporângio, membranáceos, quatro a cinco esporofilos por verticilo, 1,5-3x0,7-1 mm. Esporângios basais, reniformes, amarelos, 0,8-1x1-1,5 mm. 
Material selecionado: BRASIL. Rio de Janeiro: Itatiaia, Abrigo Massena, 10/IX/2004, Condack 242 (RB); Agulhas Negras, V/1935, Brade 14537 (RB); Brejo da Lapa, 2100 m, 5/V/2005, Ramos et al. 11 (RB); Estrada para o Planalto, 13/VII/2006, Ramos et al. 41 (RB); Prateleiras, ca. de 2550 m, II/1969, Sucre 4675 (RB); Três Picos, 1750 m, VII/1959, Strang 114 (R).

Lycopodium clavatum tem distribuição cosmopolita (Øllgaard \& Windisch 1987).

A espécie ocorre entre $600 \mathrm{~m}$ e $2500 \mathrm{~m}$ (Øllgaard \& Windisch 1987). No PNI, os espécimes formam densas populações escandentes sobre barrancos, às margens de trilhas e estradas, crescendo em locais úmidos e expostos ao sol, em altitudes que variam de 1500-2550 m.

No estudo de Lycopodium clavatum, Øllgaard \& Windisch (1987) descreveram duas variações de ápice dos microfilos para os espécimes brasileiros: um membranáceo e outro filiforme. Ambas as variações foram encontradas na área de estudo.

3.3. Lycopodium jussiaei Desv. ex Poir., Encycl. Suppl. 3: 543. 1813 [1814]. Tipo: Peru (holótipo P-Jussieu 658; isótipo $\mathrm{LG})$.

Fig. 40-42

Esporófitos terrestres. Caule primário reptante, 4-6 mm diâm. (incluindo os microfilos), 2-3 mm diâm. (excluindo os microfilos), pardacento; microfilos ascendentes, alterno-verticilados, lineares, ápice obtuso, terminando em uma membrana erosa, margem inteira, membranáceos, quatro a cinco microfilos por verticilo, 4-5x1 mm. Ramo secundário ereto, $23,5-50 \mathrm{~cm}$ compr., 4-7,5 mm diâm. (incluindo os microfilos), 1-1,5 mm diâm. (excluindo os microfilos), amarelo, filotaxia dorsiventral; microfilos subdecussados, dispostos em duas fileiras laterais e duas ventrais. Microfilos laterais patentes, assimétricos, ápice agudo, margem inteira, coriáceos, 2-4x1,5-1,7 mm. Microfilos ventrais adpressos a ascendentes, lineares, ápice agudo, terminando em uma membrana erosa, margem inteira, membranáceos, 2,5-3x0,3 mm. Estróbilos pedunculados; pedúnculos simples ou furcados, 1,5-8,5 cm compr.; dois a três estróbilos por pedúnculo, 25-64x5$10 \mathrm{~mm}$. Esporofilos alterno-verticilados, ovados, ápice acuminado, margem eroso-denticulada, base hastada na inserção do esporângio, mambranáceos, quatro esporofilos por verticilo, 4-5x1,8-2 mm. Esporângios basais, reniformes, amarelos, 0,6x1 mm.

Material examinado: BRASIL. Minas Gerais: Itamonte, 1900 m, 16/IX/1961, Pereira 5770 (RB). Rio de Janeiro: Itatiaia, Sem localidade, 2200 m, 25/V/1902, Dusén 172 (R); 2200 m, VI/1913, Tamandaré-Toledo Jr \& Brade 826 (RB).

A espécie distribui-se pela América Tropical (Øllgaard \& Windisch 1987).

Lycopodium jussiaei localiza-se em regiões de vegetação arbustivo-arbórea (Øllgaard \& Windisch 1987). No Brasil, a espécie ocorre somente na área do Parque Nacional do
Itatiaia, no interior de mata, em altitudes que variam entre 1900-2200 m.

A falta de dados específicos sobre as localidades, onde os espécimes foram coletados, dificultou a localização das populações no campo. Além disso, os registros mais recentes, para o PNI, datam de 1961.

3.4. Lycopodium thyoides Humb. \& Bonpl. ex Willd., Sp. Pl. 5: 18. 1810. Tipo: Venezuela, Silla de Caracas, Humboldt s.n. (holótipo B-Willd. 19352).

Fig. 43-44

Esporófitos terrestres ou rupícolas. Caule primário longo-reptante, 2-3 mm diâm. (incluindo os microfilos), 1,5-2 mm diâm. (excluindo os microfilos), verde-oliva; microfilos adpressos a ascendentes, alterno-verticilados, lineares a subulados, ápice longo-acuminado, margem inteira, papiráceos, dois a cinco microfilos por verticilo, 2,54,5x0,3-0,7 mm. Ramo secundário ereto, $11-29 \mathrm{~cm}$ compr., 1-4 mm diâm. (incluindo os microfilos), 0,7-0,8 mm diâm. (excluindo os microfilos), verde, filotaxia dorsiventral; microfilos decussados, dispostos em duas fileiras laterais, uma dorsal e uma ventral. Microfilos laterais patentes, oblongos, ápice acuminado, margem inteira, coriáceos, 2-4x0,6-1 mm. Microfilos dorsais adpressos, lanceolados, ápice acuminado, margem inteira, coriáceos, 2-3x0,7-0,8 mm. Microfilos ventrais adpressos, subulados, ápice acuminado, margem inteira, papiráceos, 0,7-1,5x0,3-0,4 mm. Estróbilos pedunculados; pedúnculos furcados, 5,5-15,2 cm compr.; três a oito estróbilos por pedúnculo, 15-50x2-4 mm. Esporofilos alterno-verticilados, deltóides, ápice longo-cuspidado, margem inteira a crenulada, base longo-hastada na inserção do esporângio, membranáceos, três esporofilos por verticilo, 1,5-2,7x1,2-2 mm. Esporângios basais, reniformes, amarelos, $0,5-0,7 \times 1-1,5 \mathrm{~mm}$.

Material selecionado: BRASIL. Minas Gerais: Bocaina de Minas, Alto dos Brejos, 16/VI/2004, Sylvestre \& Condack 1743 (RB). Rio de Janeiro: Itatiaia, Brejo da Lapa, 15/VI/2004, Sylvestre \& Condack 1719 (RB); Descida do Massena, 18/II/1958, Andrade 71 (R); Estrada para o Planalto, 13/VII/2006, Ramos et al. 42 (RB); Trilha para os Três Picos, 1650 m, 30/V/2006, Ramos et al. 23 (RB).

Lycopodium thyoides distribui-se por toda América tropical (Øllgaard \& Windisch 1987). No Brasil, localiza-se nos estados do Piauí, Minas Gerais, Rio de Janeiro, São Paulo, Paraná e Santa Catarina.

A espécie é encontrada de $720 \mathrm{~m}$ a $2700 \mathrm{~m}$ (Øllgaard \& Windisch 1987). Na área de estudo, é observada formando densas populações escandentes em barrancos, à margem de estradas ou trilhas, em locais abertos e úmidos, em altitudes que variam entre $1500 \mathrm{~m}$ e $2400 \mathrm{~m}$.

Lycopodium thyoides e L. jussiaei podem ser facilmente confundidos à primeira vista. A primeira possui ramo secundário com filotaxia decussada (microfilos dispostos em quatro fileiras, em dois planos) e microfilos trimórficos, 

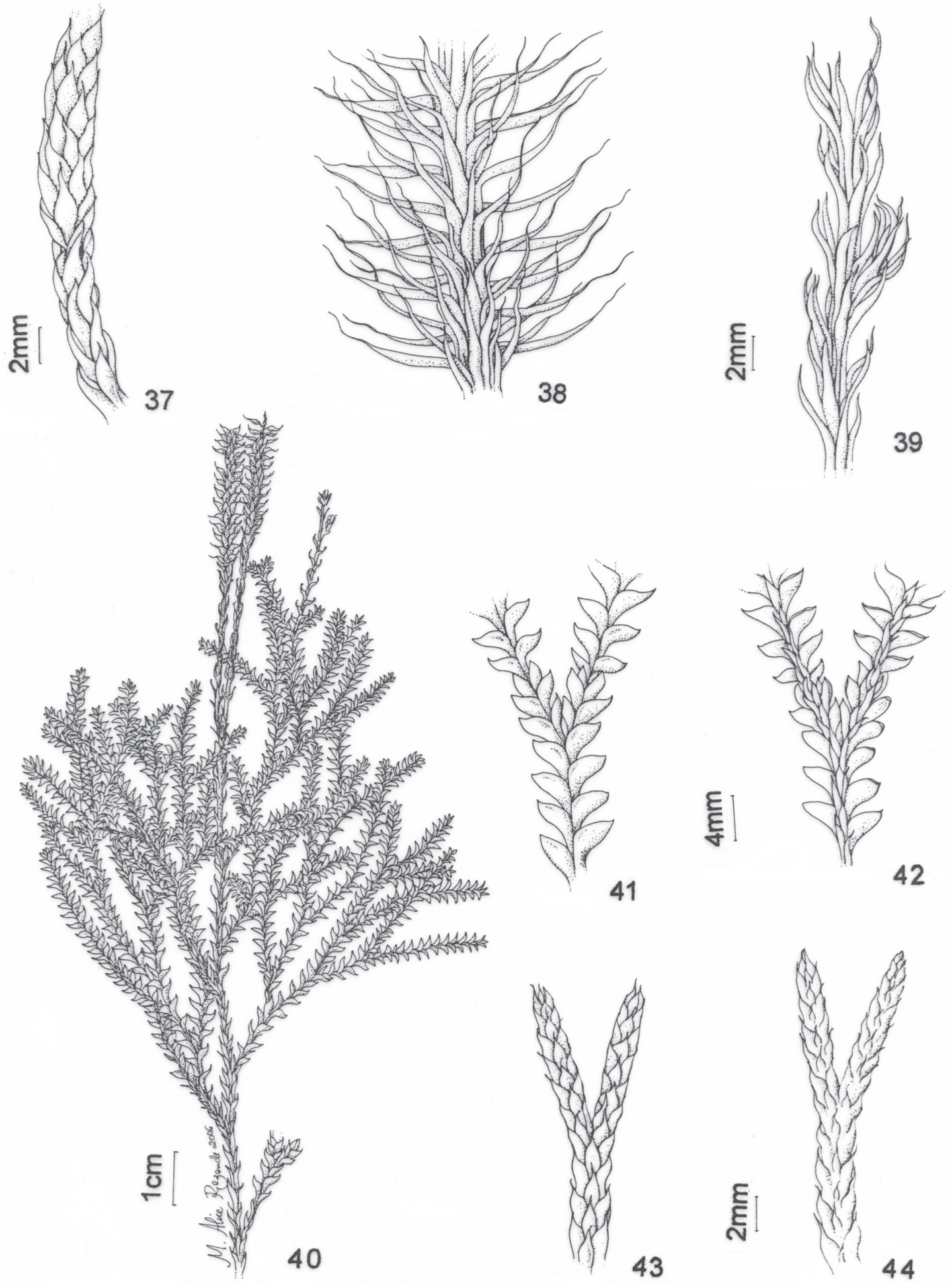

Figura 37. Lycopodium assurgens Fée - Estróbilo evidenciando os esporofilos ovados (Ramos et al. 46). Figuras 38-39. Lycopodium clavatum L. 38. Porção mediana do ramo secundário, microfilos com ápice filiforme (Ramos et al. 41). 39. Porção mediana do ramo secundário, microfilos com ápice membranáceo (Ramos et al. 11). Figuras 40-42. Lycopodium jussiaei Desv. ex Poir. 40. Hábito. 41. Vista dorsal de parte do ramo secundário mostrando os microfilos laterais. 42. Vista ventral de parte do ramo secundário mostrando os microfilos laterais e os ventrais (Tamandaré-Toledo Jr. \& Brade 826). Figuras 43-44. Lycopodium thyoides Humb. \& Bonpl. ex Willd. 43. Vista dorsal de parte do ramo secundário mostrando os microfilos laterais e os dorsais. 44. Vista ventral de parte do ramo secundário mostrando os microfilos laterais e os ventrais (Ramos et al. 42). 
enquanto a segunda apresenta ramo secundário com filotaxia subdecussada (microfilos dispostos em três fileiras, em dois planos) e microfilos dimórficos.

\section{Discussão}

As espécies terrestres de Huperzia apresentaram caule ereto a ascendente, com raízes adventícias emergindo do caule em um tufo basal. Porém, em alguns espécimes de Huperzia badianiana, Huperzia nuda e no único representante de Huperzia pungentifolia observou-se estas raízes partindo perpendicularmente ao caule quando decumbente. Pita et al. (2006a) verificou que, em Huperzia, as raízes adventícias originam-se no periciclo do caule e percorrem todo o córtex paralelamente ao sistema vascular (raízes corticais). É provável, então, que um caule, inicialmente ascendente, ao tombar e tocar lateralmente o solo permita o desenvolvimento de raízes (corticais) perpendiculares ao caule. As espécies epífitas ou rupícolas apresentaram caule pendente.

A mesma variação na posição do caule de Huperzia não foi encontrada em Lycopodiella e Lycopodium. Lycopodiella possui caule primário reptante, longo-reptante ou sarmentoso, com ramo secundário ereto ou prostrado (em Lycopodiella bradei). Lycopodium possui caule primário reptante, longo-reptante ou rizomatoso, com ramo secundário ereto. Ambos os gêneros predominam em substratos terrestres.

Alguns autores, como Pita et al. (2006b), indicam a ocorrência de heterofilia (microfilos e esporofilos completamente diferenciados) em Huperzia heterocarpon. Entretanto, ao se comparar as espécies observadas com aquelas realmente dimorfas (Huperzia biformis e Huperzia erythrocaulon), pôdese verificar que a morfologia dos esporofilos não varia em relação a dos microfilos. Em Huperzia heterocarpon, como em outras espécies do gênero, ocorre um alargamento na base dos microfilos (esporofilos) para portar os esporângios em formação, como observado por Øllgaard (1987) e Labiak \& Prado (1998). A única variação observada para alguns espécimes de Huperzia heterocarpon foi uma redução gradual no tamanho do esporofilo em direção à porção distal do caule, classificada por Øllgaard (1987) como heterofilia gradual.

As espécies de Huperzia distribuem-se por todas as fitofisionomias ocorrentes no PNI, com a maioria restrita às formações florestais montana e alto-montana (47\%). Outras espécies distribuem-se além do domínio florestal, sendo encontradas, concomitantemente, nos campos de altitude (33\%). Esse resultado era esperado, uma vez que as espécies de Huperzia são preferencialmente epífitas. Lycopodiella apresentou maior percentual de espécies (75\%) restritas aos campos de altitude. Em Lycopodium, as espécies restritas aos campos de altitude ou ocorrendo ao longo das formações florestais e campos de altitude detiveram índices iguais ( $50 \%$ cada).

A análise da distribuição geográfica dos táxons revelou que somente duas espécies possuem ampla distribuição geográfica: Lycopodium clavatum (Cosmopolita) e Lycopodiella cernua (Pantropical). A maioria dos táxons apresenta distribuição restrita para o Brasil (57\%). Dentre as espécies exclusivamente brasileiras, oito são restritas ao eixo Sudeste e Sul, três são endêmicas para o Sudeste e duas se distribuem de Roraima a Santa Catarina.

Esse alto percentual de endemismos para o território brasileiro foi registrado por Øllgaard (1996) que, ao estudar a distribuição das espécies neotropicais de Huperzia, posicionou o Brasil em segundo lugar no índice de endemismos para o gênero, com 26 espécies (68\%), logo após os Andes, com 69 espécies (73\%). Com relação às espécies de Huperzia encontradas no PNI, 73,3\% são endêmicas para o Brasil.

Estudos florísticos realizados no PNI privilegiaram as Lycopodiaceae ocorrentes na região alto-montana. O incremento na amostragem e a revisão de materiais anteriormente coletados resultaram no acréscimo de seis espécies: quatro restritas aos ambientes florestais (Huperzia heterocarpon, Huperzia loefgreniana, Huperzia mollicoma e Huperzia quadrifariata) e duas aos campos de altitude (Huperzia pungentifolia e Lycopodiella geometra).

Das 23 espécies de Lycopodiaceae encontradas no PNI, duas não apresentaram registros recentes para a área. Lycopodiella bradei é classificada como criticamente em perigo e Lycopodium jussiaei, em perigo, segundo os critérios da IUCN (Fundação Biodiversitas 2005). A não localização das populações no campo foi dificultada pela ausência de dados específicos sobre o local de coleta, possivelmente associada aos constantes incêndios e pastoreio que sofrem a região alto-montana. Morim (2006) afirma que estes incêndios podem ser considerados como a ameaça mais constante à vegetação e à flora do PNI, especialmente na região altomontana, onde predomina a vegetação herbácea-arbustiva. Estes dados demonstraram o risco potencial de extinção de Lycopodiella bradei e Lycopodium jussiaei no PNI, justificando um aumento de estratégias conservacionistas na área.

\section{Agradecimentos}

Ao Programa Mata Atlântica (JBRJ), pelo apoio logístico; à equipe do PNI, pelo auxílio; à CAPES, pela bolsa concedida a primeira autora; e ao CNPq, pela bolsa de produtividade a segunda autora.

\section{Referências bibliográficas}

Brade, A.C. 1956. A Flora do Parque Nacional do Itatiaia. Boletim do Parque Nacional do Itatiaia 5: 1-85.

Dusén, P. 1905. Sur la flore de la Serra do Itatiaya au Brésil. Archivos do Museu Nacional do Rio de Janeiro 13: 1-119.

Dusén, P. 1955. Contribuições para a flora do Itatiaia. Boletim do Parque Nacional do Itatiaia 4: 9-91.

Fundação Biodiversitas. 2005. Lista da Flora Brasileira Ameaçada de Extinção. http://www.biodiversitas.org.br/florabr/consulta_fim.asp (acesso em 09/03/2008).

Holmgren, P.K.; Holmgren, N.H. \& Barnett, L.G. 1990. Index Herbariorum: the herbaria of the world. New York, New York Botanical Garden.

Labiak, P.H. \& Prado, J. 1998. Pteridófitas epífitas da Reserva Volta Velha, Itapoá - Santa Catarina, Brasil. Boletim do Instituto de Botânica 11: $1-79$.

Lellinger, D.B. 2002. A Modern Multilingual Glossary for Taxonomic Pteridology. Washington, American Fern Society.

Morim, M.P. 2006. Leguminosae arbustivas e arbóreas da Floresta 
Atlântica do Parque Nacional do Itatiaia, sudeste do Brasil: padrões de distribuição. Rodriguésia 57(1): 27-45.

Øllgaard, B. 1979. Studies in Lycopodiaceae, II. The branching patterns and infrageneric groups of Lycopodium sensu lato. American Fern Journal 69: 49-61.

Øllgaard, B. 1987. A revised classification of the Lycopodiaceae s. 1. Opera Botanica 92: 153-178.

Øllgaard, B. 1990. Lycopodiaceae. Pp. 31-39. In: K. Kubitzki (ed.). The families and genera of vascular plants, Vol. 1. Berlin, SpringerVerlag.

Øllgaard, B. 1992. Neotropical Lycopodiaceae - an overview. Annals of the Missouri Botanical Garden 79: 687-717.

Øllgaard, B. 1993. Lycopodiaceae. Pp. 16-66. In: R.M. Tryon \& R.G. Stolze (eds.). Pteridophyta of Peru. Part VI: Marsileaceae-Isoetaceae. Fieldiana (Botany).

Øllgaard, B. 1995. Diversity of Huperzia (Lycopodiaceae) in Neotropical Montane Forests. Pp. 349-358. In: S. P. Churchill (ed.). Biodiversity and Conservation of Neotropical Montane Forests. New York, The New York Botanical Garden.

Øllgaard, B. 1996. Neotropical Huperzia (Lycopodiaceae) - distribution of species richness. Pp. 93-100. In: J.M. Camus; M. Gibby \& R.J. Johns (eds.). Pteridology in Perspective. Kew, Royal Botanic Gardens.
Øllgaard, B. \& Windisch, P.G. 1987. Sinopse das Lycopodiáceas do Brasil. Bradea 5: 1-43.

Pita, P. B.; Menezes, N.L. \& Prado, J. 2006a. Morfologia interna e externa de raiz e caule de espécies de Huperzia Bernh. (Lycopodiaceae Pteridophyta) do Brasil. Hoehnea 33(4): 495-510.

Pita, P.B.; Menezes, N.L. \& Prado, J. 2006b. Morfologia externa e interna das folhas vegetativas, esporofilos e esporângios de espécies de Huperzia Bernh. (Lycopodiaceae - Pteridophyta) do Brasil. Revista Brasileira de Botânica 29(1): 115-131.

Pryer, K.M.; Schuettpelz, E.; Wolf, P.G.; Schneider, H.; Smith, A.R.; Cranfill, R. 2004. Phylogeny and evolution of ferns (Monilophytes) with a focus on the early leptosporangiate. American Journal of Botany 91(10): 1582-1598.

Tryon, R. M. 1972. Endemic areas and geographic speciation in Tropical American ferns. Biotropica 4(3): 121-131.

Ule, E. 1895. Relatório de uma excursão botânica feita na Serra do Itatiaia. Archivos do Museu Nacional do Rio de Janeiro 9: 185-223.

Veloso, H.P.; Rangel Filho, A.L.R. \& Lima, J.C.A. 1991. Classificação da vegetação brasileira, adaptada a um sistema universal. Rio de Janeiro, IBGE, Departamento de Recursos Naturais e Estudos Ambientais.

Wikström, N. 2001. Diversification and Relationships of Extant Homosporous Lycopods. American Fern Journal 91(3): 150-165.

Versão eletrônica do artigo em www.scielo.br/abb e http://www.botanica.org.br/acta/ojs 